\title{
THE MACROECONOMIC EFFECTS OF FISCAL POLICY
}


EUROSYSTEM

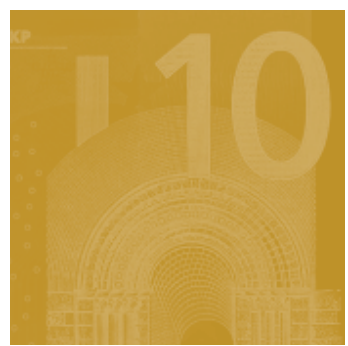

\title{
WORKING PAPER SERIES
}

NO 99 I I JANUARY 2009

\section{THE MACROECONOMIC EFFECTS OF FISCAL POLICY'}

\author{
by António Afonso ${ }^{2}$
}

and Ricardo M. Sousa ${ }^{3}$

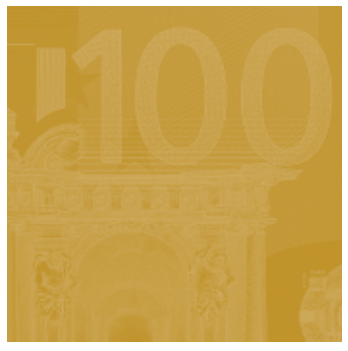

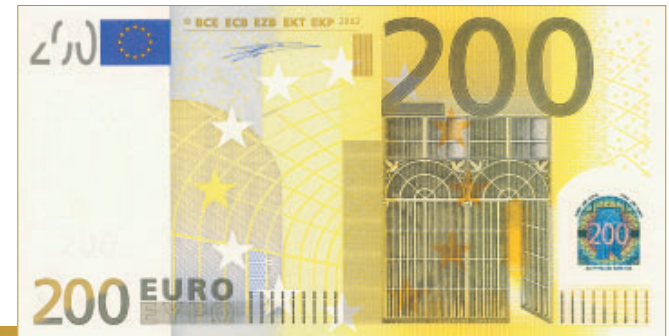

In 2009 all ECB publications feature a motif taken from the $€ 200$ banknote.
This paper can be downloaded without charge from http://www.ecb.europa.eu or from the Social Science Research Network electronic library at http://ssrn.com/abstract_id= $=1311394$.

I We are grateful to Mårten Blix, Ad van Riet, Jürgen von Hagen and to an anonymous referee for helpful comments and suggestions, to Boris Hofmann, Bernhard Manzke, and Sandro Momigliano for help with the data, and to Silvia Albrizio, and Matthijs Lof for research assistance. The opinions expressed herein are those of the authors and do not necessarily reflect those of the European Central Bank or the Eurosystem. Ricardo Sousa would like to thank the Fiscal Policies Division of the European Central Bank for its hospitality. 2 European Central Bank, Directorate General Economics, Kaiserstraße 29, D-603II Frankfurt am Main, Germany. ISEG/TULisbon - Technical University of Lisbon, Department of Economics; UECE - Research Unit on Complexity and Economics; R. Miguel Lupi 20, 1249-078 Lisbon, Portugal. UECE is supported by FCT (Fundação para a Ciência e a Tecnologia, Portugal), financed by ERDF and Portuguese funds; e-mails: antonio.afonso@ecb.europa.eu; aafonso@iseg.utl.pt

3 University of Minho, Department of Economics and Economic Policies Research Unit (NIPE), Campus of Gualtar, 47I0-057 - Braga, Portugal; London School of Economics, Department of Economics and Financial Markets Group (FMG), Houghton Street, London WC2 2AE, 


\section{(C) European Central Bank, 2009}

\section{Address}

Kaiserstrasse 29

60311 Frankfurt am Main, Germany

\section{Postal address}

Postfach 160319

60066 Frankfurt am Main, Germany

\section{Telephone}

+496913440

Website

http://www.ecb.europa.eu

Fax

+496913446000

\section{All rights reserved.}

Any reproduction, publication and reprint in the form of a different publication, whether printed or produced electronically, in whole or in part, is permitted only with the explicit written authorisation of the ECB or the author(s).

The views expressed in this paper do not necessarily reflect those of the European Central Bank

The statement of purpose for the ECB Working Paper Series is available from the ECB website, http://www.ecb.europa. eu/pub/scientific/wps/date/html/index. en.html

ISSN 1725-2806 (online) 


\section{CONTENTS}

Abstract

Non-technical summary

1 Introduction

2 Literature

9

3 Modelling strategy

4 Empirical analysis

4.1 Building the data set

4.2 Results

4.3 Fiscal shocks and government debt feedback

5 Conclusion

References

Appendices

Figures

European Central Bank Working Paper Series 


\begin{abstract}
We investigate the macroeconomic effects of fiscal policy using a Bayesian Structural Vector Autoregression approach. We build on a recursive identification scheme, but we: (i) include the feedback from government debt (ii); look at the impact on the composition of output; (iii) assess the effects on asset markets (via housing and stock prices); (iv) add the exchange rate; (v) assess potential interactions between fiscal and monetary policy; (vi) use quarterly data, particularly, fiscal data; and (vii) analyze empirical evidence from the U.S., the U.K., Germany, and Italy. The results show that government spending shocks, in general, have a small effect on GDP; lead to important "crowding-out" effects; have a varied impact on housing prices and generate a quick fall in stock prices; and lead to a depreciation of the real effective exchange rate. Government revenue shocks generate a small and positive effect on both housing prices and stock prices that later mean reverts; and lead to an appreciation of the real effective exchange rate. The empirical evidence also shows that it is important to explicitly consider the government debt dynamics in the model.
\end{abstract}

Keywords: fiscal policy, Bayesian Structural VAR, debt dynamics

JEL Classification: C11, C32, E62, H62 


\section{Non-technical summary}

This paper provides a detailed evaluation of the effects of fiscal policy on economic activity. First, we consider the effects of fiscal policy on the composition of GDP, namely, by estimating the impact of government spending and government revenue shocks on private consumption and private investment. Consequently, we are able to identify the potential "crowding-out" effects of fiscal policy on the private sector. Second, we also ask how stock prices and housing prices are affected by fiscal policy shocks. To the extent that we find a link between them, we look at the persistence of the effects and assess whether the reaction is quantitatively similar and/or exhibits asymmetry instead. Third, we look at the impact of fiscal policy on the external sector via the effects on exchange rate. Fourth, we analyze the effects of fiscal policy shocks on the growth rate of monetary aggregates, therefore, assessing the existence of a credit channel in the transmission of the shocks and wealth effects associated to the changes in the (long-term) interest rate.

Another novelty of the paper is that we explicitly include the feedback from government debt in our estimations. In fact, while equilibrium structural models are normally solved by imposing the government's intertemporal budget constraint, that does not happen with VAR-based fiscal policy models. We deal with this limitation of previous literature by considering the response of fiscal variables to the level of the debt.

In addition, an important contribution of the paper is the use of quarterly fiscal data, which allows us to identify more precisely the effects of fiscal policies. We analyze empirical evidence from the U.S., the U.K., Germany, and Italy, respectively, for the periods 1970:3-2007:4, 1964:2-2007:4, 1980:3-2006:4, and 1986:2-2004:4. The set of quarterly fiscal data, is taken from national accounts (in the case of the U.S. and the U.K.) or computed by drawing on the higher frequency (monthly) availability of fiscal cash data (for Germany and Italy). To the best of our knowledge the use of such fiscal data set has not yet been used in this strand of economic modelling.

The most relevant findings of this paper can be summarized as follows. Government spending shocks (i) have, in general, a small effect on GDP; (ii) do not impact significantly on private consumption; (iii) have a negative effect on private investment; (iv) have a varied effect on housing prices that ranges from a positive and persistent effect to a negative effect and gradual recovery according to the country under consideration, a pattern that depends on the effect on (long-term) interest rates; 
(v) lead to a quick fall in stock prices; (vi) do not impact significantly on the price level and the average cost of refinancing the debt; (vii) have a small and positive effect on the growth rate of monetary aggregates; (viii) lead to a depreciation of the real effective exchange rate; and (ix) have a positive and persistent impact on productivity.

On the other hand, government revenue shocks: (i) have a positive (although lagged) effect on GDP and private investment, as a result of the fiscal consolidation; (ii) a positive effect on both housing prices and stock prices that later mean reverts, but the exact impact depends on the effects on (long-term) interest rates; (iii) in general, do not have an impact on the price level; and (iv) lead to an appreciation of the real effective exchange rate.

When we explicitly take into account the feedback from government debt in our framework, the effects of fiscal policy on (long-term) interest rates and GDP become more persistent and these variables are also more responsive to the shock. Finally, the results do not seem to support the existence of important stabilizing effects of the debt level on the primary budget balance. 


\section{Introduction}

Compared to the large empirical literature on the effects of monetary policy on economic activity, fiscal policy has received less attention, a feature that contrasts with the public debates on its role. The government deficit and debt limits of the Stability and Growth Pact in the context of the Economic and Monetary Union (EMU), the possibility of independent institutions running fiscal policy, the creation of fiscal policy committees, the influence of regulation in the structure of market incentives, and the Balanced Budget Amendment in the U.S., are based on the assumption that fiscal policy can be an effective tool for stabilizing business cycles.

This paper provides a detailed evaluation of the effects of fiscal policy on economic activity. First, we consider the effects of fiscal policy on the composition of GDP, namely, by estimating the impact of government spending and government revenue shocks on private consumption and private investment as in Gali et al. (2007). Consequently, we are able to identify the potential "crowding-out" effects of fiscal policy on the private sector. Second, we also ask how asset markets (via stock prices and housing prices) are affected by fiscal policy shocks. To the extent that we find a link between them, we look at the persistence of the effects and assess whether the reaction is quantitatively similar and/or exhibits asymmetry instead. Third, we look at the impact of fiscal policy on the external sector through the effects on exchange rate in line with Monacelli and Perotti (2006). Fourth, we analyze the effects of fiscal policy shocks on the growth rate of monetary aggregates, therefore, assessing the existence of a credit channel in the transmission of the shocks and the wealth effects associated to the changes in the (long-term) interest rate. In practice, we aim at assessing the potential interaction between fiscal policy and monetary policy in the spirit of Davig and Leeper (2005), Chung et al. (2007), and Gali and Monacelli (2008). Fifth, we look at the impact of fiscal policy on the labour market, namely, by assessing its impact on wages and productivity.

We identify fiscal policy shocks using a recursive identification scheme and estimate a Bayesian Structural Vector Autoregression (B-SVAR) model, therefore, accounting for the posterior uncertainty of the impulse-response functions. ${ }^{1}$

Another novelty of the paper is that we explicitly include the feedback from government debt in our estimations. In fact, while equilibrium structural models are

1 Christiano et al. (2005) use a recursive identification scheme to identify the monetary policy shock. We follow the same approach but in the context of identification of the fiscal policy shock. 
normally solved by imposing the government's intertemporal budget constraint (see Chung and Leeper, 2007), this does not happen with VAR-based fiscal policy models. We deal with this limitation of previous literature by following Favero and Giavazzi (2008), and, as a result, we consider the response of fiscal variables to the level of the government debt.

In addition, an important contribution of the paper is the use of quarterly fiscal data, which allows us to identify more precisely the effects of fiscal policies. We analyze empirical evidence from the U.S., the U.K., Germany, and Italy, respectively, for the periods 1970:3-2007:4, 1964:2-2007:4, 1980:3-2006:4, and 1986:2-2004:4. The set of quarterly fiscal data, is taken from national accounts (in the case of the U.S. and the U.K.) or computed by drawing on the higher frequency (monthly) availability of fiscal cash data (for Germany and Italy). To the best of our knowledge, such fiscal data set has not yet been used in this strand of economic modelling.

The most relevant findings of this paper can be summarized as follows. Government spending shocks (i) have, in general, a small effect on GDP; (ii) do not impact significantly on private consumption; (iii) have a negative effect on private investment; (iv) have a varied effect on housing prices that ranges from a positive and persistent effect to a negative effect and gradual recovery according to the country under consideration, a pattern that depends on the effect on (long-term) interest rates; (v) lead to a quick fall in stock prices; (vi) do not impact significantly on the price level and the average cost of refinancing the debt; (vii) have a small and positive effect on the growth rate of monetary aggregates; (viii) lead to a depreciation of the real effective exchange rate; and (ix) have a positive and persistent impact on productivity.

On the other hand, government revenue shocks: (i) have a positive (although) lagged) effects on GDP and private investment, as a result of the fiscal consolidation; (ii) a positive effect on both housing prices and stock prices that later mean reverts, but the exact impact depends on the effects on (long-term) interest rates; (iii) in general, do not have an impact on the price level; and (iv) lead to an appreciation of the real effective exchange rate.

When we explicitly take into account the feedback from government debt in our framework, the effects of fiscal policy on (long-term) interest rates and GDP become more persistent and these variables are also more responsive to the shock. Finally, the results do not seem to support the existence of a significant stabilizing response of the budget balance to the debt level. In fact, there is only weak evidence suggesting that: (i) 
government spending falls when the debt-to-GDP ratio is above its mean (for the U.S. and Italy in the second half of the sample); and (ii) government revenue increases when the debt-to-GDP ratio is above its mean (in the case of the U.K. and only for the second half of the sample).

The rest of the paper is organized as follows. Section two reviews the related literature. Section three explains the empirical strategy used to identify the effects of fiscal policy shocks, and to take into account the uncertainty regarding the posterior impulse-response functions. Section four provides the empirical analysis and discusses the results. Section five concludes with the main findings and policy implications.

\section{Literature}

Despite the large literature on the impact of monetary policy on economic activity, fiscal policy has received less attention and its importance for economic stabilization has been typically neglected. The recent financial turmoil has, however, revived the interest of academia, central bankers and governments on the role of fiscal policy.

We review in this section the existing evidence of the effects on the composition of output, on housing and stock prices, on long-term interest rates, on exchange rates, and on the interaction between monetary and fiscal policy.

\section{Composition of output}

For the U.S., different approaches have been used in the identification of the fiscal policy shock. Ramey and Shapiro (1998) use a "narrative approach" to isolate political events, and find that, after a brief rise in government spending, nondurable consumption displays a small decline while durables consumption falls. Following the same approach, Edelberg et al. (1999) show that episodes of military build-ups have a significant and positive short-run effect on U.S. output and consumption, and that the sign of the response does not change when anticipation effects are taken into account. Fatás and Mihov (2001) use a Cholesky ordering to identify fiscal shocks and show that increases in government expenditures are expansionary, but lead to an increase in private investment that more than compensates for the fall in private consumption. ${ }^{2}$

\footnotetext{
${ }^{2}$ This result goes against the empirical findings of the standard RBC model, which generally predicts a decline in private consumption in response to a rise in government spending. With infinitely-lived Ricardian households, an increase in government spending lowers the present value of after-tax income,
} 
Blanchard and Perotti (2002) use information about the elasticity of fiscal variables to identify the automatic response of fiscal policy, and find that expansionary fiscal shocks increase output, have a positive effect on private consumption, and a negative impact on private investment. More recently, using sign restrictions on the impulse-response functions and identifying the unexpected variation in government spending by a positive response of expenditure for up to four quarters after the shock, Mountford and Uhlig (2005) find a negative effect in residential and non-residential investment. ${ }^{3}$

Similar studies applied to other countries are relatively scarce, largely due to the limited availability of quarterly public finance data, and, in addition, do not provide a consensual view. Perotti (2004) investigates the effects of fiscal policy in Australia, Canada, Germany and the U.K., and finds a relatively large positive effect on private consumption and no response of private investment. Biau and Girard (2005) find a cumulative multiplier of government spending larger than one, and positive reactions of private consumption and private investment in France. De Castro and Hernández de Cos (2006) use data for Spain and show that, while there is a positive relationship between government expenditure and output in the short-term, in the medium and long-term expansionary spending shocks only lead to higher inflation and lower output. HeppkeFalk et al. (2006) use cash data for Germany, and find that a positive shock in government spending increases output and private consumption, although the effect is relatively small. Giordano et al. (2007) show that, in Italy, government expenditure has positive and persistent effects on output and on private consumption.

and thus generates a negative wealth effect on consumption (Aiyagari et al., 1990; Baxter and King, 1993; Christiano and Eichenbaum, 1992; and Fatás and Mihov, 2001). It also induces a rise in the quantity of labour supplied at any given wage, leading to a lower real wage, and higher employment and output. If persistent, the increase in employment leads to a rise in the expected return of capital, and may boost investment (Gali et al., 2007). In contrast, the IS-LM model predicts that consumption should rise in response to a positive government spending shock. When consumers behave in a non-Ricardian fashion, their consumption is a function of their current disposable income. The effect of an increase in government spending will depend on how it is financed, and on the response of investment (Blanchard, 2003). Under the assumption of a constant money supply, the rise in consumption is followed by an investment decline (due to a higher interest rate). If the central bank holds the interest rate constant, the effect on investment is nil.

${ }^{3}$ Giavazzi and Pagano (1990) and Alesina and Ardagna (1998) have uncovered the presence of "nonKeynesian effects" (i.e., negative spending multipliers) during large fiscal consolidations, with output rising significantly despite large cuts in government spending. Perotti (1999) also obtains such findings, but only in circumstances of "fiscal stress" (unusually high debt-to-GDP ratios). In addition, Afonso (2008c) suggests that there is some evidence in favour of the existence of expansionary fiscal consolidations, for a few budgetary items (general government final consumption, social transfers, and taxes). 


\section{Housing prices}

Despite the analysis of the effects of fiscal policy on macroeconomic variables (such as GDP, consumption and its components, or investment and its components), and the empirical importance of housing over the business cycle, there are only a small number of papers that discuss the empirical link between economic policy and housing prices, and the focus has mainly been on the effects of monetary policy.

McCarthy and Peach (2002) show that the magnitude of the response of residential investment in the U.S. to a change in monetary policy has not changed over time despite the fundamental restructuring of the housing finance system. Chirinko et al. (2004) study the relationship between stock prices, house prices, and real activity, but focus on the role that asset prices play in the formulation of monetary policy. Iacoviello and Minetti (2003) emphasize the housing market as creating a credit channel for monetary policy. Aoki et al. (2004) argue that there is a collateral transmission mechanism to consumption. Iacoviello (2005) looks at the monetary policy-house price to consumption channel and finds a significant effect on house prices. Iacoviello and Neri (2007) show that housing prices are very sensitive to monetary policy shocks. Julliard et al. (2007) suggest that monetary policy contractions have a large and significantly negative impact on real housing prices, but the reaction is extremely slow. On the other hand, monetary policy shocks do not seem to cause a significant impact on stock markets.

\section{Stock prices}

As with housing prices, the link between fiscal policy and stock markets has not been explored yet, and the attention has been normally targeted towards the role played by monetary policy.

Rigobon and Sack (2002, 2003) and Craine and Martin (2003) use a heteroskedasticity-based estimator and find a significant response of the stock market to shocks in the interest. Bernanke and Kuttner (2005) show that a hypothetical unanticipated 25-basis-point cut in the Federal funds rate target is associated with about a $1 \%$ increase in broad stock indexes.

\section{Long-term interest rates}

Gale and Orszag (2003) argue that there are two important reasons for why budget deficits may raise nominal interest rates: (i) public deficits reduce aggregate 
savings when private savings do not increase by the same amount (i.e. in the absence of Ricardian equivalence) and there are no compensating foreign capital inflows, therefore, leading to a decrease in the supply of capital; and (ii) deficits increase the stock of government debt and, consequently, the outstanding amount of government bonds (relative to other financial assets). In this case, there is a "portfolio effect", as a higher interest rate on government bonds would be required in order to incentive investors to hold the additional bonds.

While some studies find that interest rates tend to increase after a rise in the deficit, others do not (Engen and Hubbard, 2004). The empirical findings seem to depend on whether expected or current budget deficits are used as explanatory variables (Upper and Worms, 2003; Brook, 2003; Laubach, 2003), and also on whether yield differentials in Europe with respect to Germany (Codogno et al., 2003) or interest rate swap spreads are used as the dependent variable (Goodhart and Lemmen, 1999; Afonso and Strauch, 2007).

For Europe, the existing evidence points either to a significant (although small) effect (Bernoth et al., 2003; Codogno et al., 2003; Afonso and Strauch, 2007; Faini, 2004), or to the absence of impact (Heppke-Falk and Hüfner, 2004). For the U.S., the effect seems to be substantially larger (Gale and Orszag, 2002).

\section{Exchange rates}

Kim and Roubini (2003) show that a budget deficit shock leads to an improvement in the trade balance. Corsetti and Müller (2006) assess the response of the trade, while Perotti and Monacelli (2006) focus on the joint response of trade balance, consumption and real exchange rate. The authors find that a rise in government spending induces real exchange rate depreciation and a trade balance deficit.

\section{Interaction between monetary and fiscal policy}

Ferrero (2006) analyzes optimal monetary and fiscal policy setting in a currency union with two countries. The author includes a role for distortionary taxation and government debt, which leads to a modified optimal targeting rule for the union as a whole. Beetsma and Jensen (2005) and Gali and Monacelli (2008) have analyzed the role of fiscal stabilization policy in the context of a monetary union. Monetary policy is conducted by a common central bank, while fiscal policy is implemented at the country 
level. The authors show that there is a stabilizing role for fiscal policy that goes beyond the efficient provision of public goods.

\section{Modelling strategy}

The modelling strategy adopted consists in the estimation of the following Structural VAR (SVAR)

$$
\begin{gathered}
\underbrace{\Gamma(L)}_{n \times n} \underbrace{X_{t}}_{n \times 1}+\gamma_{i} d_{t-1}=\Gamma_{0} X_{t}+\Gamma_{1} X_{t-1}+\ldots+\gamma_{i} d_{t-1}=c+\varepsilon_{t} \\
d_{t}=\frac{1+i_{t}}{\left(1+\pi_{t}\right)\left(1+\mu_{t}\right)} d_{t-1}+\frac{G_{t}-T_{t}}{P_{t} Y_{t}} \\
v_{t}=\Gamma_{0}^{-1} \varepsilon_{\mathrm{t}},
\end{gathered}
$$

where $\varepsilon_{t} \mid X_{s}, s<t \sim \mathrm{N}(0, \Lambda), \Gamma(L)$ is a matrix valued polynomial in positive powers of the lag operator $L, n$ is the number of variables in the system, $\varepsilon_{t}$ are the fundamental economic shocks that span the space of innovations to $X_{t}$, and $v_{t}$ is the VAR innovation.

Equation (2) refers to the government's intertemporal budget constraint, and $i_{t}$, $G_{t}, T_{t}, \pi_{t}, Y_{t}, P_{t,}, \mu_{t}$ and $d_{t}$ represent, respectively, the interest rate (or the average cost of debt refinancing), government primary expenditures and government revenues, inflation, GDP, price level, real growth rate of GDP, and the debt-to-GDP ratio at the beginning of the period $t$. Appendix A shows how one can express the government's intertemporal budget constraint given in (2).

Following Favero and Giavazzi (2008), this specification includes the feedback from government debt, an assumption that is potentially important in the determination of the effects of fiscal policy shocks for a number of reasons. ${ }^{4}$ First, when fiscal authorities have a Ricardian behaviour and care about the stabilization of debt, a feedback from the level of debt ratio to government revenue and government spending is expected. Second, the debt dynamics may influence interest rates as they depend on future expected monetary policy and the risk premium. ${ }^{5}$ Third, debt may have an impact

\footnotetext{
4 Note that while Chung and Leeper (2007) linearize the intertemporal budget constraint and impose it as a set of cross-equation restrictions on the estimated VAR coefficients, we follow Favero and Giavazzi (2008) by adding the government debt to the VAR and appending a non-linear budget identity to accumulate debt.

${ }^{5}$ Giavazzi et al. (2000) find that an increase in taxes can raise private consumption in the case of fiscal consolidations it moves the economy from an unsustainable fiscal path to a sustainable one. Romer and Romer (2007) also find that the effect of a U.S. tax shock on output depends on whether it is motivated by the government's desire to stabilize the debt, or is unrelated to the stance of fiscal policy.
} 
on inflation and output (Barro, 1974; Kormendi, 1983; Canzoneri et al., 2001). ${ }^{6}$ Therefore, it is important to allow for the fact that government revenues, government spending, real GDP growth, inflation and the interest rate are linked by the government intertemporal budget constraint. ${ }^{7}$

Fiscal policy is characterized as follows:

$$
\begin{aligned}
& G_{t}=f\left(\Omega_{t}\right)+\varepsilon_{t}^{G} \\
& T_{t}=g\left(\Omega_{t}\right)+\varepsilon_{t}^{T}
\end{aligned}
$$

where, $G_{t}$ is the government spending, $T_{t}$ is the government revenue, $f$ and $g$ are linear functions, $\Omega_{t}$ is the information set, and $\varepsilon_{t}^{G}$ and $\varepsilon_{t}^{T}$ are, respectively, the government spending shock and the government revenue shock. The shocks $\varepsilon_{t}^{G}$ and $\varepsilon_{t}^{T}$ are orthogonal to the elements in $\Omega_{t}$.

We follow a recursive identification scheme and assume that the variables in $X_{t}$ can be separated into 3 groups: (i) a subset of $n_{1}$ variables, $X_{l t}$, whose contemporaneous values appear in the policy function and do not respond contemporaneously to the fiscal policy shocks; (ii) a subset of $n_{2}$ variables, $X_{2 t}$, that respond contemporaneously to the fiscal policy shocks and whose values appear in the policy function only with a lag; and (iii) the policy variables in the form of government expenditure, $G_{t}$, and/or government revenue, $T_{t}$.

The recursive assumptions can be summarized by $X_{t}=\left[X_{1 t}, G_{t}, T_{t}, X_{2 t}\right]$ and

$$
\Gamma_{0}=\left[\begin{array}{ccc}
\underbrace{\gamma_{11}}_{n_{1} \times n_{1}} & \underbrace{0}_{n_{1} \times 2} & \underbrace{0}_{n_{1} \times n_{2}} \\
\underbrace{\gamma_{21}}_{2 \times n_{1}} & \underbrace{\gamma_{22}}_{2 \times 2} & \underbrace{0}_{2 \times n_{2}} \\
\underbrace{\gamma_{31}}_{n_{2} \times n_{1}} & \underbrace{\gamma_{32}}_{n_{2} \times 2} & \underbrace{\gamma_{33}}_{n_{2} \times n_{2}}
\end{array}\right] .
$$

The two upper blocks of zeros correspond, respectively, to the assumptions that the variables in $X_{1 t}$ do not respond to the fiscal policy shock either directly or indirectly. This approach delivers a correct identification of the fiscal policy shock but not of the other shocks in the system. ${ }^{8}$ In practice, we include in our system the same variables as

\footnotetext{
${ }^{6}$ Afonso (2008a, b) reports that it would be wise to reject the debt neutrality hypothesis for the EU and that higher government indebtedness can actually deter private consumption.

7 Appendix A derives the government's intertemporal budget constraint described by (2).

${ }^{8}$ Since the fiscal policy shock is identified regardless of the ordering restrictions among the non-policy variables, we can put arbitrary $O s$ in the non-policy blocks of $\Gamma_{0}$ in order to obtain $(n-1) n / 2$ linearly
} 
in Christiano et al. (2005), but also add housing price among the $X_{1 t}$ variables, that is, we allow the policy authority to react contemporaneously to changes in the housing market. We also include the stock market index and the exchange rate in $X_{2 t}$.

Finally, we assess the posterior uncertainty about the impulse-response functions by using a Monte Carlo Markov-Chain (MCMC) algorithm. Appendix B provides a detailed description of the computation of the error bands.

\section{Empirical analysis}

\subsection{Building the data set}

This section provides a summary description of the data employed in the empirical analysis. A detailed description is provided in Appendix C. We use quarterly data for four countries: U.S., U.K., Germany and Italy. All the variables are in natural logarithms unless stated otherwise.

For the identification of the fiscal policy shocks, we use the following variables. The variables in $X_{1 t}$ - the ones predetermined with respect to fiscal policy innovations are GDP, private consumption, GDP deflator, private investment, wages, and productivity. To these variables, we add for the housing price index (or the median sales price of new houses sold, in the case of the U.S.), the housing starts (only for the U.S.), and the average cost of government debt financing (or the yield to maturity of long-term government bonds). The variables in $X_{2 t}$ - the ones allowed to react contemporaneously to fiscal policy shocks - are the profits, and the money growth rate, to which we add the real exchange rate, the S\&P500 Index (for the U.S.), the FTSE-All Shares Index (for the U.K.), and the MSCI index (for Germany and Italy). As measure of the fiscal policy instruments we use either the government expenditures (in which case, the government revenues are included in $X_{1 t}$ ) or the government revenues (in which case, the government expenditures are included in $X_{1 t}$ ). We include a constant (or quarterly seasonal dummies), and the government debt-to-GDP ratio in the set of exogenous variables. For Germany, we also consider two dummies: (i) one dummy for 1991:1, corresponding to the German reunification; and (ii) another dummy for 2000:3, to capture the spike in government revenue due to the sale of UMTS (Universal Mobile Telecommunications System) licenses.

independent restrictions and to get consistent impulse-responses (Christiano et al, 1999). As a result, the Choleski decomposition emerges as a particular case, where the restrictions are imposed such that $\Gamma_{0}$ becomes a lower triangular matrix. 
Due to limitations of the data, housing starts are included only in the U.S. while, for Germany and Italy, profits are not included. For the U.K., we use the $M_{4}$ growth rate instead of the $M_{2}$ growth rate. Table 1 shows for each country the list of variables included in the estimation of the SVAR.

Among the set of variables included in the SVAR, the average government debt cost servicing deserves a special attention. We obtain the average implicit interest rate by dividing the net interest payments by the government debt at time $t-1$. Figure 1 plots the average debt cost servicing and the nominal (annualized) GDP growth for the U.S, the U.K., Germany, and Italy. It shows that countries have, in general, moved from a situation where nominal GDP growth exceeded the cost of financing the debt to a situation where the converse has been true.

The quarterly fiscal data refers to the Federal Government spending and revenue in the case of the U.S.A., and the Public Sector spending and revenue in the case of the U.K. In both cases, quarterly fiscal data is available directly from national accounts. As for Germany and Italy, we compute the quarterly series of government spending and revenue using the fiscal cash data, which is monthly published by the fiscal authorities of both countries. In this case, data for government spending and revenue refer to the Central Government and are available in a cash basis.

The data cover the following samples: 1970:3-2007:4, in the case of the U.S.A.; 1971:2-2007:4, in the case of the U.K.; 1979:2-2006:4, in the case of Germany; and 1986:2-2004:4, in the case of Italy.

Figures 2, 3, 4, and 5 provide a comparison of the annual values of such quarterly fiscal data with the annual national accounts data provided by the European Commission (Ameco database). It is interesting to observe that the patterns of both series are rather similar. ${ }^{9}$ Moreover, in most of the cases, the levels themselves are also close.

Finally, Figure 6 plots the observed government debt-to-GDP ratio and the implicit debt-to-GDP ratio, that is, the one that would emerge by including the feedback from government debt. It shows that, despite some small discrepancies in the case of Italy, the implicit series for the debt-to-GDP ratio tracks pretty well the actual series. The small differences may be due to: (i) the consideration, in some cases, of the central

9 In this context, Pérez (2007) argues that, for some EU countries', intra-annual cash fiscal information can be used to improve the forecasting and monitoring of the annual General Government deficit in terms of ESA95. 
government revenues and expenditures instead of the general government revenues and expenditures; (ii) the use, for some countries, of the federal government debt instead of the general government debt; (iii) the presence of seigniorage, which is ignored in our framework; (iv) the fact that GDP growth rates and inflation rates are computed as logarithmic differences which can introduce some approximation errors; (v) the possible existence of stock-flow adjustments; and (vi) the inclusion of seasonally adjusted measures, namely, in the case of government revenues and expenditures.

Table 1 summarises the variables to be included in each country's B-SVAR.

Table 1 - List of variables included in the B-SVAR.

\begin{tabular}{|c|c|c|c|c|c|}
\hline & & U.S. & U.K. & Germany & Italy \\
\hline \multirow[b]{2}{*}{$X_{1, t}$} & $\mathrm{HP}_{\mathrm{t}}$ & $\sqrt{ }$ & $\sqrt{ }$ & $\sqrt{ }$ & $\sqrt{ }$ \\
\hline & $\mathrm{HS}_{\mathrm{t}}$ & $\sqrt{ }$ & & & \\
\hline \multirow{8}{*}{ 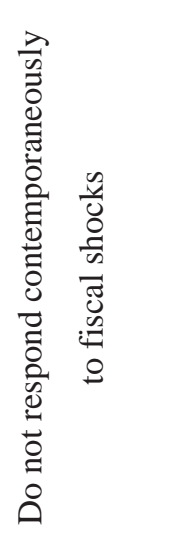 } & $\mathrm{i}_{\mathrm{t}}$ & $\sqrt{ }$ & $\sqrt{ }$ & $\sqrt{ }$ & $\sqrt{ }$ \\
\hline & $Y_{t}$ & $\sqrt{ }$ & $\sqrt{ }$ & $\sqrt{ }$ & $\sqrt{ }$ \\
\hline & $\mathrm{C}_{\mathrm{t}}$ & $\sqrt{ }$ & $\sqrt{ }$ & $\sqrt{ }$ & $\sqrt{ }$ \\
\hline & $P_{t}$ & $\sqrt{ }$ & $\sqrt{ }$ & $\sqrt{ }$ & $\sqrt{ }$ \\
\hline & $\mathrm{I}_{\mathrm{t}}$ & $\sqrt{ }$ & $\sqrt{ }$ & $\sqrt{ }$ & $\sqrt{ }$ \\
\hline & $\mathrm{W}_{\mathrm{t}}$ & $\sqrt{ }$ & $\sqrt{ }$ & $\sqrt{ }$ & $\sqrt{ }$ \\
\hline & $\operatorname{Prod}_{t}$ & $\sqrt{ }$ & $\sqrt{ }$ & $\sqrt{ }$ & $\sqrt{ }$ \\
\hline & $\mathrm{T}_{\mathrm{t}}\left(\right.$ or $\left.\mathrm{G}_{\mathrm{t}}\right)$ & $\sqrt{ }$ & $\sqrt{ }$ & $\sqrt{ }$ & $\sqrt{ }$ \\
\hline instrument & $\mathrm{G}_{\mathrm{t}}\left(\right.$ or $\left.\mathrm{T}_{\mathrm{t}}\right)$ & $\sqrt{ }$ & $\sqrt{ }$ & $\sqrt{ }$ & $\sqrt{ }$ \\
\hline \multicolumn{6}{|l|}{$\mathrm{X}_{2, \mathrm{t}}$} \\
\hline \multirow{4}{*}{ 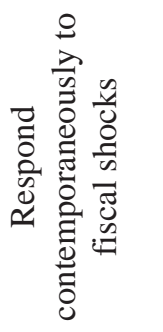 } & $\operatorname{Prof}_{t}$ & $\sqrt{ }$ & $\sqrt{ }$ & & \\
\hline & $\mathrm{M}_{\mathrm{t}}$ & $\sqrt{ }$ & $\sqrt{ }$ & $\sqrt{ }$ & $\sqrt{ }$ \\
\hline & $\mathrm{SP}_{\mathrm{t}}$ & $\sqrt{ }$ & $\sqrt{ }$ & $\sqrt{ }$ & $\sqrt{ }$ \\
\hline & $\mathrm{ExR}_{\mathrm{t}}$ & $\sqrt{ }$ & $\sqrt{ }$ & $\sqrt{ }$ & $\sqrt{ }$ \\
\hline
\end{tabular}

Note: $\mathrm{HP}_{\mathrm{t}}-$ housing price index; $\mathrm{HS}_{\mathrm{t}}-$ housing starts; $\mathrm{i}_{\mathrm{t}}-$ average cost of refinancing debt or yield to maturity of long-term government bonds; $\mathrm{Y}_{\mathrm{t}}-$ gross domestic product; $\mathrm{C}_{\mathrm{t}}-$ private consumption; $\mathrm{P}_{\mathrm{t}}-$ GDP deflator; $\mathrm{I}_{\mathrm{t}}$ - private investment; $\mathrm{W}_{\mathrm{t}}-$ wages; Prod $_{\mathrm{t}}-$ productivity; $\mathrm{T}_{\mathrm{t}}$ (or $\mathrm{G}_{\mathrm{t}}$ ) - government revenue (government spending); $\mathrm{G}_{\mathrm{t}}\left(\right.$ or $\mathrm{T}_{\mathrm{t}}$ ) government spending (government revenue); Prof $f_{t}$ profits; $M_{t}$ - monetary growth rate $\left(M_{2}\right.$, for U.S., Germany and Italy; $M_{4}$, for U.K.); $\mathrm{SP}_{\mathrm{t}}-$ stock prices; ExR $\mathrm{t}_{\mathrm{t}}$ - effective exchange rate. Exogenous variables: constant (or quarterly seasonal dummies); Germany dummies (1991:1, reunification; 2000:3, UMTS revenues). 


\subsection{Results}

The starting point is the estimation of a Bayesian Structural VAR (B-SVAR) that does not include the feedback from government debt, that is, where equation (2) is not considered. Then, we compare the results with the ones that emerge from estimating specifications (1), (2), and (3).

Figures 7, 9, 11, and 13 show the impulse-response functions to a fiscal policy shock. The solid line refers to the median response when the VAR is estimated without the government budget constraint, and the dashed lines are, respectively, the median response and the 68 percent posterior confidence intervals from the VAR estimated by imposing the government budget constraint. The confidence bands are constructed using a Monte Carlo Markov-Chain (MCMC) algorithm based on 500 draws.

We also show in Figures 8, 10, 12, and 14 the forecast-error variance decompositions to a fiscal policy shock, imposing the budget constraint. The thinner line corresponds to the median estimate, and the dashed lines indicate the 68 percent posterior confidence intervals estimated by using a Monte-Carlo Markov-Chain algorithm based on 500 draws.

U.S.

Figure $7 \mathrm{a}$ displays the impulse-response functions of all variables in $X_{t}$ to a shock in government spending in the U.S.

In the case we do not include the debt feedback, it can be seen that government spending declines steadily following the shock, and it roughly vanishes after 6 quarters. The effects on GDP are small, positive, but not significant. However, they reveal a change in the composition of its major components: while government spending shocks do not seem to have an impact on private consumption, the effects on private investment are rather negative, supporting the idea of a "crowding-out" effect. ${ }^{10}$ In addition, there is a small and negative effect on the average cost of debt. In what concerns the reaction of asset markets, the empirical evidence suggests that while there is a positive effect on housing prices that persists for almost 12 quarters, the reaction of stock prices is rather small, negative and less persistent. Looking at the interaction between fiscal and

\footnotetext{
${ }^{10}$ Fatás and Mihov (2001), when looking at the response to changes in different components of government expenditures, find that increases in government consumption are always expansionary, while increases in public investment do not have a significant impact on output. Here, we can not analyse some of these policy experiments because we have not made explicit the role of different components of government spending.
} 
monetary policies, there is some support of the idea that an increase in government spending leads to a growth in the monetary aggregate, but the effect disappears after 4 quarters. Finally, the results suggest that after a government spending shock, the real effective exchange rate depreciates persistently for almost 12 quarters, although the magnitude is relatively small.

When we include the debt dynamics in the model, the effects of a government spending shock on GDP become smaller. Nevertheless, the effects on private investment remain negative while private consumption slightly increases, illustrating the wealth effects from government debt. On the other hand, and contrary to the previous findings, there is a small but negative effect on the average cost of refinancing the debt, which is eventually due to the rise in government revenues that follows the shock in government spending. The reaction of asset markets is similar to the model without the government constraint: there is a positive and persistent effect on housing prices, while the reaction of stock prices is smaller due to the debt dynamics and the portfolio reallocation.

Figure $7 \mathrm{~b}$ shows the impulse-response functions to a shock in government revenue. The results suggest that government revenue declines steadily following the shock which erodes after 8 quarters. Contrary to a shock in government spending, the effects on GDP are negative, very persistent, and the trough is reached at after at after 10 quarters. They also reveal a change in the composition of GDP's major components: while private consumption is negatively impacted by a positive shock in government revenues, the effect on private investment is roughly insignificant, despite a small positive initial reaction. That is, in this case, the "crowding-out" effect works mainly through the consumption channel. In what concerns the reaction of asset markets, the empirical evidence suggests that the effects of revenue shocks tend to be rather insignificant: despite a very small positive impact on housing and stock prices that persists for around 6 quarters, the effects then revert and disappear. Profits tend to fall after an initial increase while productivity is negatively affected by the shock. Finally, the results show that after a government revenue shock, the real effective exchange rate slightly appreciates.

Figure 8a plots the forecast error-variance decomposition of all variables in $X_{t}$ to a shock in government spending. Government spending shocks explain a very small percentage (around 1 to $2 \%$ ) of the forecast-error variance decomposition of the 
majority of the variables. Similar conclusions can be drawn for the government revenue shock (Figure 8b).

$U . K$.

The impulse-response functions to a shock in government spending in the U.K are shown in Figure 9a.

While private consumption is not impacted by the spending shock, the effects on private investment are rather negative and very persistent, suggesting the idea of a "crowding-out" effect via investment. The dynamics of monetary aggregates suggest that $M_{4}$ growth rate falls after the shock, supporting the idea of a monetary policy tightening. Housing prices fall after the spending shock while stock prices decline only briefly. The effects on wages and productivity tend to be positive. Finally, the results suggest that after a government spending shock, the real effective exchange rate depreciates persistently for almost 20 quarters, in accordance with the findings for the U.S.

Figure $9 \mathrm{~b}$ shows the impulse-response functions to a shock in government revenue. They support the idea of a "crowding-in" effect: private investment reacts positively to the shock. The effects on housing prices are also positive, but the reaction takes place with a lag of around 8 quarters. Although small in magnitude, the effects on profits are negative, while the national currency depreciates in real terms.

Figure 10a plots the forecast-error variance decomposition of all variables in the VAR to a shock in government spending. It shows that the shock accounts for $10 \%$ of the forecast-error variance of the exchange rate, $5 \%$ of the housing prices, and only $3 \%$ of stock prices.

Figure $10 \mathrm{~b}$ displays the forecast-error variance decompositions and shows that government revenue shocks represents a large percentage $(80 \%)$ of the forecast-error in government revenues and a small share of the forecast-error for the majority of the variables.

\section{Germany}

We now look at the impulse-response functions a shock in government spending for Germany (Figure 11a). The effects on GDP are negative, reflecting the fall in private investment. There is, therefore, evidence of a "crowding-out" effect. Government spending shocks have a negative and persistent effect on the price level, although very 
small in magnitude. Housing prices fall after around 10 quarters while stock prices drop immediately after the. Both productivity and wages fall with a lag of about 8 to 12 quarters.

When we include the feedback from the government debt, the cost of refinancing debt becomes positive, therefore, emphasizing the importance of account for debt dynamics.

Figure $11 \mathrm{~b}$ plots the impulse-response functions to a shock in government revenue. Similarly to the U.S., the results show that government revenue declines quickly after the shock, eroding after 2 quarters. ${ }^{11}$ Contrary to the U.S., the effects on GDP are positive (although lagged in time. They support the idea of a "crowding-in" effect as both private consumption and private investment react positively to the shock. Revenue shocks tend to be significant and positive only for housing prices. The difference between the U.K. and the German experiences lies, therefore, on the balance between the magnitude of the credit channel and the "crowding-in" effect: in the U.K., the credit channel is reinforced by a "crowding-in" effect, and, therefore, a positive shock in government revenues has an impact of the same signal in housing prices; in Germany, the "crowding-in" effect is strong enough to compensate for the rise in the interest rates (credit channel). Note also that while in the U.K. the positive revenue shock is accompanied by a fall in government spending (therefore, justifying the fall of the interest rate), in the case of Germany the shock in government revenues is followed by a positive and persistent increase in government spending (consequently, explaining the rise of the interest rate).

The forecast-error variance decompositions to a shock in government spending and to a shock in government revenue are displayed, respectively, on Figures 12a and 12b. Shocks to spending also play an important role for the forecast-error of the price level (around 10\%), GDP (9\%), government revenue (7\%) wages (close to 5\%), housing prices (around 5\%), and stock prices (5\%). In contrast, revenue shocks explain only a negligible percentage of the forecast-error variance decomposition for the majority of the variables included in the system.

\footnotetext{
${ }^{11}$ Afonso and Claeys (2008) mention that large revenue reductions unmatched by expenditure cuts have pushed the deficit beyond the 3\% threshold in Germany in 2002, putting the country in an excessive deficit situation within the EU fiscal framework.
} 
Italy

Finally, we look at the effects of a fiscal policy shock in Italy. Figure 13a displays the impulse-response functions to a shock in government spending. Despite a very small positive effect in the first quarters, GDP, private consumption, and private investment fall, suggesting a "crowding-out" effect. Government spending shocks have a positive and persistent effect on the price level. Housing prices seem to be positively affected by the shock, while stock prices fall for around 10 quarters.

Figure $13 \mathrm{~b}$ shows the impulse-response functions to a shock in government revenue. The effects on GDP, private consumption, and private investment are negative, although not persistent as they vanish after 4 to 6 quarters. In consequence, and contrary to the U.K., they support the idea of a "crowding-out" effect. Regarding the reaction of asset markets, the empirical evidence shows that the effects of government revenue shocks tend to be positive for stock prices and negative for housing prices. This suggests that while the credit-channel (that is, the fall in interest rates) impacts positively in stock markets, for housing markets that channel is annihilated by the "crowding-out" effects. Finally, the evidence suggests that, after an initial fall, both wages and productivity increase, accompanying the rise of other macroeconomic variables. This partially explains why GDP, consumption and investment start recovering after around 8 quarters.

The error-forecast variance decompositions of all variables in $X_{t}$ to a government spending shock and a government revenue shock are plotted, respectively, in Figures $14 \mathrm{a}$ and 14b. They show that fiscal variables account for small percentages of the majority of the variables in the VAR. The only exception is the money growth rate, a feature that may be explained by the interaction between fiscal policy and monetary policy in the early sample observations.

\subsection{Fiscal shocks and government debt feedback}

We now consider the potential debt feedback and estimate the following structural VAR:

$$
\begin{aligned}
& \Gamma_{0} X_{t}+\Gamma_{1} X_{t-1}+\ldots+\gamma_{i}\left(d_{t-1}-d^{*}\right)=c+\varepsilon_{t}, \\
& d_{t}=\frac{1+i_{t}}{\left(1+\pi_{t}\right)\left(1+\mu_{t}\right)} d_{t-1}+\frac{G_{t}-T_{t}}{P_{t} Y_{t}} .
\end{aligned}
$$

The specification of (7) is suggested by the empirical findings in Bohn (1998), who estimates a fiscal reaction function in which $d^{*}$ is the unconditional mean of the 
debt ratio and allow us to take into account the debt feedback. Following Bohn (1998) and Favero and Giavazzi (2008), we model the target level of the debt as a constant on the basis of the evidence of stationarity of $d$. In addition, we impose the government's intertemporal budget constraint as described by (8).

Table 2 reports the estimated coefficients on $\left(d_{t-1}-d^{*}\right)$ in the structural equations of the SVAR (government spending and government revenue). We report the coefficients (and the standard errors in brackets) taken from the estimation for the full sample and for sub-samples. In the case of the U.S., we consider two sub-samples: 1970:3 - 1987:4, corresponding to the pre-Greenspan era; and 1988:1 - 2007:4, after Greenspan. In the case of the Germany, we also split the sample in two periods: 1980:3 - 1990:4, that is before the reunification; and 1991:1 - 2006:4, that is after the reunification. For the U.K. and Italy, each sub-sample is built by splitting the entire sample in roughly two sub-samples of similar size.

Table 2 - The effect of $\left(d_{t-1}-d^{*}\right)$ in a VAR.

\begin{tabular}{|c|c|c|c|c|c|c|c|}
\hline U.S. & & $\mathrm{T}_{\mathrm{t}}$ & $\mathrm{G}_{\mathrm{t}}$ & Germany & & $\mathrm{T}_{\mathrm{t}}$ & $\mathrm{G}_{\mathrm{t}}$ \\
\hline \multirow{3}{*}{$\left(d_{t-1}-d^{*}\right)$} & $\begin{array}{c}1970: 3- \\
2007: 4 \\
(\mathrm{~N}=150)\end{array}$ & $\begin{array}{c}-0.088 \\
(0.106)\end{array}$ & $\begin{array}{l}-0.039 \\
(0.088)\end{array}$ & & $\begin{array}{c}1980: 3- \\
2006: 4 \\
(N=106)\end{array}$ & $\begin{array}{l}-0.001 \\
(0.108)\end{array}$ & $\begin{array}{c}-0.155^{* *} \\
(0.071)\end{array}$ \\
\hline & $\begin{array}{c}1970: 3- \\
1987: 4 \\
(\mathrm{~N}=70)\end{array}$ & $\begin{array}{c}0.134 \\
(0.418)\end{array}$ & $\begin{array}{c}-0.221 \\
(0.284)\end{array}$ & $\left(d_{t-1}-d^{*}\right)$ & $\begin{array}{c}1980: 3- \\
1990: 4 \\
(N=42)\end{array}$ & $\begin{array}{c}-1.479 * * \\
(0.713)\end{array}$ & $\begin{array}{c}-0.481 \\
(0.353)\end{array}$ \\
\hline & $\begin{array}{c}1988: 1- \\
2007: 4 \\
(N=80)\end{array}$ & $\begin{array}{c}-0.071 \\
(0.323)\end{array}$ & $\begin{array}{c}-0.719 * * * \\
(0.275)\end{array}$ & & $\begin{array}{c}1991: 1- \\
2006: 4 \\
(N=64)\end{array}$ & $\begin{array}{c}0.005 \\
(0.131)\end{array}$ & $\begin{array}{c}-0.080 \\
(0.071)\end{array}$ \\
\hline U.K. & & $\mathrm{T}_{\mathrm{t}}$ & $\mathrm{G}_{\mathrm{t}}$ & Italy & & $\mathrm{T}_{\mathrm{t}}$ & $\mathrm{G}_{\mathrm{t}}$ \\
\hline \multirow{3}{*}{$\left(d_{t-1}-d^{*}\right)$} & $\begin{array}{c}1964: 2- \\
2007: 4 \\
(N=175)\end{array}$ & $\begin{array}{c}0.118 * * \\
(0.048)\end{array}$ & $\begin{array}{c}-0.023 \\
(0.037)\end{array}$ & & $\begin{array}{c}1986: 2- \\
2004: 4 \\
(N=75)\end{array}$ & $\begin{array}{c}0.522 \\
(0.599)\end{array}$ & $\begin{array}{c}-3.746^{*} \\
(2.070)\end{array}$ \\
\hline & $\begin{array}{c}1964: 2- \\
1984: 4 \\
(\mathrm{~N}=83)\end{array}$ & $\begin{array}{c}-0.038 \\
(0.148)\end{array}$ & $\begin{array}{c}0.006 \\
(0.114)\end{array}$ & $\left(d_{t-1}-d^{*}\right)$ & $\begin{array}{c}1986: 2- \\
1994: 4 \\
(N=35)\end{array}$ & $\begin{array}{c}1.919 \\
(1.773)\end{array}$ & $\begin{array}{l}-0.605 \\
(7.410)\end{array}$ \\
\hline & $\begin{array}{c}1985: 1- \\
2007: 4 \\
(N=92)\end{array}$ & $\begin{array}{c}0.274 * * \\
(0.127)\end{array}$ & $\begin{array}{c}0.005 \\
(0.104)\end{array}$ & & $\begin{array}{c}1995: 1- \\
2004: 4 \\
(N=40)\end{array}$ & $\begin{array}{c}2.902 \\
(2.089)\end{array}$ & $\begin{array}{c}-16.469 * * \\
(7.002)\end{array}$ \\
\hline
\end{tabular}

Note: standard errors in brackets. ${ }^{*}, * * * * *$ - statistically significant respectively at the $10 \%, 5 \%$, and $1 \%$ levels.

For the U.S., the results do not show a significant response of revenue and primary spending to deviations of the debt-to-GDP ratio from its sample average for both the full period and the first sub-sample. In the second sub-sample (1988:1 2007:4), there is some evidence supporting a stabilizing effect of the debt level that works mainly through government spending. Indeed, one sees that when the debt-to- 
GDP ratio is above its historical mean, government primary spending decreases (the coefficient associated to $\left(d_{t-1}-d^{*}\right)$ in the government spending equation is negative and significant (-0.719).

For the U.K., the results show a stabilizing effect of the debt level on the primary budget balance that works mainly through the response of government revenues to deviations of the debt from the target level. This is, particularly, the case of the full sample and the second sub-sample (1985:1 - 2007:4). Therefore, when the debt ratio is above its sample mean, it is possible to observe an increase in government revenue (0.118, in the full sample; 0.274 , for the second sub-sample).

In the case of Germany, there is evidence of a small stabilizing effect of the debt level on the primary surplus that works through the government spending $(-0.155)$.

Finally, for Italy, one can see that when the debt ratio is above average, government spending strongly falls, particularly, in the period 1995:1-2004:4 where the coefficient associated to $\left(d_{t-1}-d^{*}\right)$ is negative and large in magnitude (-16.469). This is in line with the increase of fiscal policy imposed by the Maastricht Treaty.

\section{Conclusion}

This paper provides a detailed evaluation of the macroeconomic effects of fiscal policy.

We identify fiscal policy shocks using a recursive partial identification, and estimate a Bayesian Structural Vector Autoregression, therefore, accounting for the posterior uncertainty of the impulse-response functions. In addition, we explicitly include the feedback from government debt in our framework.

The empirical evidence suggests that government spending shocks: (i) have, in general, a small effect on GDP; (ii) do not impact significantly on private consumption; (iii) have a negative effect on private investment; (iv) have a varied effect on housing prices; (v) lead to a quick fall in stock prices; (vi) do not impact significantly on the price level and the average cost of refinancing the debt; (vii) have a small and positive effect on the growth rate of monetary aggregates; (viii) lead to a depreciation of the real effective exchange rate; and (ix) have a positive and persistent impact on productivity. In addition, government revenue shocks: (i) have a positive (although) lagged) effects on GDP and private investment; (ii) have a positive effect on both housing prices and stock prices; (iii) in general, do not impact on the price level; and (iv) lead to a appreciation of the real effective exchange rate. 
When the debt dynamics is explicitly taken into account, (long-term) interest rates and GDP become more responsive and the effects of fiscal policy on these variables also become more persistent.

Finally, the results provide weak evidence of stabilizing effects of the debt level on the primary budget balance.

A natural extension of the current work is related with the identification of the fiscal policy shocks. Blanchard and Perotti (2002) identify fiscal shocks by exploiting decision lags in fiscal policymaking. This approach assumes that: (i) discretionary government purchases and revenues are predetermined with respect to the macroeconomic variables; and (ii) it uses information about the elasticity of fiscal variables to economic activity which enables to identify the automatic response of fiscal policy. In this context, Afonso and Sousa (2008) include an identification of the automatic response of fiscal policy to macroeconomic variables such as GDP, deflator, or interest rate. Whilst narrower in scope - as its goal is solely to understand the linkages between fiscal policy and asset markets - than the present work, the estimation of a fully simultaneous system of equations in a Bayesian framework can prove to be a useful alternative approach, while allowing to assess the robustness of the effects of fiscal policy on asset markets.

\section{References}

AFONSO, A. (2008a), "Euler testing Ricardo and Barro in the EU", Economics Bulletin, 5 (16), 1-14.

AFONSO, A. (2008b), "Ricardian Fiscal Regimes in the European Union", Empirica, 35 (3), 313-334.

AFONSO, A. (2008c), "Expansionary fiscal consolidations in Europe: new evidence", Applied Economics Letters, DOI http://dx.doi.org/10.1080/13504850701719892, forthcoming.

AFONSO, A.; CLAEYS, P. (2008), "The dynamic behaviour of budget components and output", Economic Modelling, 25, 93-117.

AFONSO, A.; SOUSA, R. M. (2008), "Fiscal policy, housing and stock prices", ECB Working Paper, forthcoming.

AFONSO, A.; STRAUCH, R. (2007), "Fiscal policy events and interest rate swap spreads: some evidence from the EU", Journal of International Financial Markets, Institutions \& Money, 17 (3), 261-276. 
AIYAGARI, R.; CHRISTIANO, L.; EICHENBAUM, M. (1990), “Output, employment and interest rate effects of government consumption", Journal of Monetary Economics, 30, 73-86.

ALESINA A.; ARDAGNA, S. (1998), "Tales of fiscal adjustment", Economic Policy, 27, 489-545.

AOKI, K.; PROUDMAN, J.; VLIEGHE, G. (2004), "House prices, consumption, and monetary policy: a financial accelerator approach", Journal of Financial Intermediation, 13, 414-435.

BARRO, R. J. (1974), "Are government bonds net wealth?", Journal of Political Economy, 82(6), 1095-1117.

BAUWENS, L.; LUBRANO, M.; RICHARD, J.-F. (1999), Bayesian inference in dynamic econometric models, Oxford University Press, Oxford.

BAXTER, M.; KING, R. (1993), "Fiscal policy in general equilibrium”, American Economic Review, 83, 315-334.

BEETSMA, R.; JENSEN, H. (2005), "Monetary and fiscal policy interactions in a Micro-Founded Model of a Monetary Union", Journal of International Economics, 67, 320-352.

BERNANKE, B.; KUTTNER, K. (2005), "What explains the stock market's reaction to Federal Reserve policy?", Journal of Finance, 60(3), 1221-1257.

BERNOTH, K. J.; VON HAGEN, J.; SCHUKNECHT, L. (2003), “The determinants of the yield differential in EU government bond market”, ZEI - Center for Eurpean Integration Studies, Working Paper.

BIAU, O.; GIRARD, E. (2005), "Politique budgétaire et dynamique économique en France: l'approche VAR structurel.”, Économie et Prévision, 169-171, 1-24.

BLANCHARD, O. (2003), Macroeconomics, $3^{\text {rd }}$ ed., Prentice Hall.

BLANCHARD, O.; PEROTTI, R. (2002), "An empirical characterization of the dynamic effects of changes in government spending and taxes on output", Quarterly Journal of Economics, 117(4), 1329-1368.

BOHN, H. (1998), "The Behaviour of U.S. public debt and deficits", Quarterly Journal of Economics, 113, 949-963.

BROOK, A.-M. (2003), "Recent and prospective trends in real long-term interest: fiscal policy and other drivers", OECD Working Paper \#21.

CANZONERI, M.; CUMBY, R.; DIBA, B. (2001), "Is the price level determined by the needs of fiscal solvency", American Economic Review, 91(5), 1221-1238. 
CHIRINKO, R.; de HAAN, L.; STERKEN, E. (2004), "Asset price shocks, real expenditures, and financial structure: a multi-country analysis", Emory University, Working Paper.

CHRISTIANO, L.; EICHENBAUM, M. (1992), "Current real business cycles theories and aggregate labor market fluctuations", American Economic Review, 82, 430-450.

CHRISTIANO, L. J.; EICHENBAUM, M.; EVANS, C. L. (2005), "Nominal rigidities and the dynamic effects of a shock to monetary policy", Journal of Political Economy, 113(1), 1-45.

CHRISTIANO, L. J.; EICHENBAUM, M.; EVANS, C. L. (1999), "Monetary policy shocks: what have we learned and to what end?", in TAYLOR, J.; WOODFORD, M., eds, Handbook of Macroeconomics, 1A, Elsevier, Amsterdam.

CHUNG, H.; LEEPER, D. (2007), “What has financed government debt?”, NBER Working Paper \#13245.

CHUNG, H.; DAVIG, T.; LEEPER, E. M. (2007), "Monetary and fiscal switching", Journal of Money, Credit and Banking, 39(4), 809-842.

CODOGNO, L.; FAVERO, C.; MISSALE, A. (2003), "Yield spreads on EMU government bonds", Economic Policy, 37, 503-532.

CORSETTI, G.; MÜLLER, G. J. (2006), "Twin deficits: squaring theory, evidence and common sense", Economic Policy, 21(48), 597-638.

CRAINE, R.; MARTIN, V. (2003), "Monetary policy shocks and security market responses", University of California at Berkeley, Working Paper.

DAVIG, T.; LEEPER, E. M. (2005), "Fluctuating macro policies and the fiscal theory", NBER Working Paper \#11212.

DE CASTRO FERNÁNDEZ, F.; HERNÁNDEZ DE COS, P. (2006), “The economic effects of exogenous fiscal shocks in Spain: a SVAR approach", ECB Working Paper \#647.

EDELBERG, W.; EICHENBAUM, M.; FISHER, J. (1999), "Understanding the effects of a shock to government purchases", Review of Economics Dynamics, 2, 166-206.

ENGEN, E. M.; HUBBARD, R. G. (2004), "Federal government debt and interest rates", NBER Working Paper \#10681.

FAINI, R. (2004). "Fiscal policy and interest rates in Europe", in Public Debt, Proceedings of the Workshop in Public Finances of the Bank of Italy held in Perugia, 1-3 April 2004, 200-230. 
FATÁS, A.; MIHOV, I. (2001), “The effects of fiscal policy on consumption and employment: theory and evidence", CEPR Discussion Paper \# 2760.

FAVERO, C.; GIAVAZZI, F. (2008), "Debt and the effects of fiscal policy", University of Bocconi, Working Paper.

FERRERO, A. (2006), "Fiscal and monetary rules for a currency union”, New York University, manuscript.

GALE, W. G.; ORSZAG, P. R. (2003), "Economic effects of sustained budget deficits", National Tax Journal, 56, 463-485.

GALE, W. G.; ORSZAG, P. R. (2002), “The economic effects of long-term fiscal discipline”, Urban-Brookings Tax Policy Center, Discussion Paper.

GALI, J.; MONACELLI, T. (2008), “Optimal monetary and fiscal policy in a currency union", University of Bocconi, manuscript.

GALI, J.; PEROTTI, R. (2003), "Fiscal policy and monetary integration in Europe", University of Pompeu Fabra, Working Paper.

GALI, J.; VALLÉS, J.; LÓPEZ-SALIDO, J. D. (2007), "Understanding the effects of government spending on consumption", Journal of the European Economic Associaton, 5(1), 227-270.

GIAVAZZI, F.; PAGANO, M. (1990), "Can severe fiscal contractions be expansionary? Tales of two small european countries", in BLANCHARD, O. J.; FISCHER, S. (eds.), NBER Macroeconomics Annual, MIT Press, 75-110.

GIAVAZZI, F.; JAPPELLI, T.; PAGANO, M. (2000), "Searching for non-linear effects of fiscal policy: evidence from industrial and developing countries", European Economic Review, 44(7), 1259-1289.

GIORDANO, R.; MOMIGLIANO, S.; NERI, S.; PEROTTI, R. (2007), “The effects of fiscal policy in Italy: Evidence from a VAR model", European Journal of Political Economy, 23, 707-733.

GOODHART, C.; LEMMEN, J. J. G. (1999), “Credit risks and european government bond markets: a panel data econometric analysis", Eastern Economic Journal, 25(1), 77-107.

HEPPKE-FALK, K.H.; TENHOFEN, J.; WOLFF, G. B. (2006), “The macroeconomic effects of exogenous fiscal policy shocks in Germany: a disaggregated SVAR analysis", Deutsche Bundesbank, Discussion Paper \#41. 
HEPPKE-FALK, K.H.; HÜFNER, F. (2004), "Expected budget deficits and interest rate swap spreads - evidence for France, Germany and Italy”, Deutsche Bundesbank, Discussion Paper \#40.

IACOVIELLO, M. (2005), "House prices, borrowing constraints, and monetary policy in the business cycle", American Economic Review, 95(3), 739-764.

IACOVIELLO, M.; MINETTI, R. (2003), "The credit channel of monetary policy: evidence from the housing market", Boston College, Working Paper.

IACOVIELLO, M.; NERI, S. (2007), "The role of housing collateral in an estimated two-sector model of the US economy", Boston College, Working Paper.

JULLIARD, C.; MICHAELIDES, A.; SOUSA, R. M. (2008), "Housing prices and monetary policy", London School of Economics and Political Science, Working Paper.

KIM, J.-Y. (1994), "Bayesian asymptotic theory in a time series model with a possible nonstationary process", Econometric Theory, 10(3), 764-773.

KIM, S.; ROUBINI, N. (2003), "Twin deficits or twin divergence? Fiscal policy, current account, and the real exchange rate in the U.S.", New York University, manuscript.

KORMENDI, R. C. (1983), "Government debt, government spending, and private sector behavior", American Economic Review, 73, 994-1010.

LAUBACH, T. (2003), "New evidence on the interest rate effects of budget deficits and debt", Board of Governors of the Federal Reserve System, Finance and Economics Discussion Paper \#12.

MCCARTHY, J.; PEACH, R. (2002), "Monetary policy transmission to residential investment", Federal Reserve Bank of New York Economic Policy Review, 8(1), 139158.

MONACELLI, T.; PEROTTI, R. (2006), "Fiscal policy, the trade balance, and the real exchange rate: implications for international risk sharing", University of Bocconi, manuscript.

MOUNTFORD, A.; UHLIG, H. (2005), "What are the effects of fiscal policy shocks?", Humboldt-Universität zu Berlin Working Paper SFB \#649.

PÉREZ, J. (2007), "Leading indicators for euro area government deficits", International Journal of Forecasting, 23, 259-275.

PEROTTI, R. (2004), "Estimating the effects of fiscal policy in OECD countries", University of Bocconi, Working Paper. 
PEROTTI, R. (1999), "Fiscal policy in good times and bad", Quarterly Journal of Economics, 114, 1399-1436.

RAMEY, V.; SHAPIRO, M. (1998), "Costly capital reallocation and the effects of government spending”, Carnegie Rochester Conference on Public Policy, 48, 145194.

RIGOBON, R.; SACK, B. (2003), "Measuring the reaction of monetary policy to the stock market", Quarterly Journal of Economics, 118(2), 639-670.

RIGOBON, R.; SACK, B. (2002), "The impact of monetary policy on asset prices", Finance and Economics Discussion Series 2002-4, Board of Governors of the Federal Reserve System.

ROMER, C.; ROMER, D. H. (2007), "The macroeconomic effects of tax changes: estimates based on a new measure of fiscal shocks", NBER Working Paper \#13264.

SCHERVISH, M. J. (1995), Theory of statistics, Springer, New York.

SIMS, C.; ZHA, T. (1999), "Error bands for impulse-responses", Econometrica, 67(5), 1113-1155.

UPPER, C.; WORMS, A. (2003), "Real long-term interest rates and monetary policy: a cross-country perspective", BIS Papers, 19, 234-257.

ZELLNER, A. (1971). An introduction to bayesian inference in econometrics, Wiley, New York.

\section{Appendix A. The government's intertemporal budget constraint}

The government's intertemporal budget constraint can be written as:

$$
B_{t}=\left(1+i_{t}\right) B_{t-1}+\left(G_{t}-T_{t}\right)
$$

where $B_{t}$ represents the stock of debt at the end of period $t, B_{t-1}$ is the stock of debt at the end of period $t-1, G_{t}$ is the government primary spending during the period $t, T_{t}$ is the government revenue during the period $t$, and $i$ is the nominal interest.

Dividing both sides of the last identity by the nominal GDP, $P_{t} Y_{t}$, where $P_{t}$ is the general price level, and $Y_{t}$ represents the real GDP, one obtains:

Finally, noting that

$$
\frac{B_{t}}{P_{t} Y_{t}}=\left(1+i_{t}\right) \frac{B_{t-1}}{P_{t} Y_{t}}+\frac{\left(G_{t}-T_{t}\right)}{P_{t} Y_{t}}
$$

$$
\frac{B_{t-1}}{P_{t} Y_{t}}=\frac{B_{t-1}}{P_{t-1} Y_{t-1}} \bullet \frac{P_{t-1} Y_{t-1}}{P_{t} Y_{t}}=\frac{B_{t-1}}{P_{t-1} Y_{t-1}}\left[\frac{1}{\left(1+\pi_{t}\right)\left(1+\mu_{t}\right)}\right]
$$

where $\pi_{t}$, and $\mu_{t}$, represent, respectively, the inflation rate and the growth rate of real GDP, and defining by lowercase letters the variables expressed as ratio of GDP, that is

$$
d_{t}:=\frac{B_{t}}{P_{t} Y_{t}} ; d_{t-1}:=\frac{B_{t-1}}{P_{t-1} Y_{t-1}} ; g_{t}:=\frac{G_{t}}{P_{t} Y_{t}} ; \text { and } t_{t}:=\frac{T_{t}}{P_{t} Y_{t}}
$$

we can get the following expression 


$$
d_{t}=\frac{\left(1+i_{t}\right)}{\left(1+\pi_{t}\right)\left(1+\mu_{t}\right)} d_{t-1}+\left(g_{t}-t_{t}\right) .
$$

This is identical to equation (2) in the text.

\section{Appendix B. Confidence bands of the impulse-response functions}

The impulse-response function to a one standard-deviation shock under the normalization of $\Lambda=\boldsymbol{I}$ is given by:

$$
B(L)^{-1} \Gamma_{0}^{-1} \text {. }
$$

To assess uncertainty regarding the impulse-response functions, we follow Sims and Zha (1999) and construct confidence bands by drawing from the Normal-InverseWishart posterior distribution of $B(L)$ and $\Sigma$

$$
\begin{aligned}
& \left.\beta\right|_{\Sigma} \sim \mathrm{N}\left(\hat{\beta}, \Sigma \otimes\left(X^{\prime} X\right)^{-1}\right) \\
& \Sigma^{-1} \sim \operatorname{Wishart}\left((T \hat{\Sigma})^{-1}, T-m\right)
\end{aligned}
$$

where $\beta$ is the vector of regression coefficients in the VAR system, $\Sigma$ is the covariance matrix of the residuals, the variables with a hat denote the corresponding maximumlikelihood estimates, $X$ is the matrix of regressors, $T$ is the sample size and $m$ is the number of estimated parameters per equation (see Zellner, 1971; Schervish, 1995; and Bauwens et al., 1999).

\section{Appendix C. Data description and sources}

\section{C.1 U.S. Data}

Housing Sector

Housing prices are measured using two sources: (a) the Price Index of New One-Family Houses sold including the Value of Lot provided by the U.S. Census, an index based on houses sold in 1996, available for the period 1963:1-2006:3; and (b) the House Price Index computed by the Office of Federal Housing Enterprise Oversight (OFHEO), available for the period 1975:1-2007:4. Data are quarterly, seasonally adjusted.

Housing Market Indicators

Other Housing Market Indicators are provided by the U.S. Census. We use the Median Sales Price of New Homes Sold including land and the New Privately Owned Housing Units Started. We seasonally adjust quarterly data for the Median Sales Price of New Homes Sold including land using Census X12 ARIMA, and the series comprise the period 1963:1-2007:4. The data for the New Privately Owned Housing Units Started are quarterly (computed by the sum of corresponding monthly values), seasonally adjusted and comprise the period 1959:1-2007:4.

\section{GDP}

The source is Bureau of Economic Analysis, NIPA Table 1.1.5, line 1. Data for GDP are quarterly, seasonally adjusted, and comprise the period 1947:1-2007:4.

\section{Consumption}

The source is Bureau of Economic Analysis, NIPA Tables 2.3.5 and 2.6. Consumption is defined as: (a) the expenditure in non-durable consumption goods (line 6) and services (line 13) excluding housing services (line 14); and (b) the expenditure in non- 
durable consumption goods (line 3) and services (line 4). Data are quarterly, seasonally adjusted, and comprise the period 1947:1-2007:4.

Price Deflator

All variables were deflated by the GDP deflator. Data are quarterly, seasonally adjusted, and comprise the period 1967:1-2007:4. The source is the Bureau of Economic Analysis, NIPA Tables 1.1.5 and 1.1.6, line 1.

Investment

The source is Bureau of Economic Analysis, NIPA Table 1.1.5. Investment is defined as the gross private domestic investment (line 6) excluding residential investment (line 11). Data are quarterly, seasonally adjusted, and comprise the period 1947:1-2007:4.

Wages

The source is Bureau of Economic Analysis, NIPA Tables 2.1 and 2.6. Wages are defined as the sum of wages and salary disbursements (line 3). Data are quarterly, seasonally adjusted, and comprise the period 1947:1-2007:4.

Productivity

Productivity is defined as the Nonfarm Business Output Per Hour Index (1992=100) ("PRS85006093"). Data are quarterly, seasonally adjusted, and comprise the period 1947:1-2007:4. The source is the Bureau of Labour Statistics.

Profits

The source is Bureau of Economic Analysis, NIPA Table 1.14. Profits are defined as the profits before tax without IVA and CCAdj ("A446RC1", line 32). Data are quarterly, seasonally adjusted, and comprise the period 1947:1-2007:4.

Monetary Aggregate

Monetary Aggregate corresponds to $\mathrm{M}_{2}$. Data are quarterly, seasonally adjusted, and comprise the period 1960:1-2007:4. The sources are the OECD, Main Economic Indicators (series "USA.MABMM201.STSA") and the Board of Governors of the Federal Reserve System, Release H6.

Stock Market Index

Stock Market Index corresponds to S\&P 500 Composite Price Index (close price adjusted for dividends and splits). Data are quarterly (computed from monthly series by using end-of-period values), and comprise the period 1950:1-2007:4.

Exchange Rate

The source is the Bank for International Settlements (BIS). Exchange Rate corresponds to real effective exchange rate (series "RNUS"). Data are quarterly (computed from monthly series by using end-of-period values), and comprise the period 1964:1-2007:4.

\section{Government Spending}

The source is Bureau of Economic Analysis, NIPA Table 3.2. Government Spending is defined as primary government expenditure, obtained by subtracting from total Federal Government Current Expenditure (line 39) net interest payments at annual rates (obtained as the difference between line 28 and line 13). Data are quarterly, seasonally adjusted, and comprise the period 1960:1-2007:4. 
Government Revenue

The source is Bureau of Economic Analysis, NIPA Table 3.2. Government Revenue is defined as government receipts at annual rates (line 36). Data are quarterly, seasonally adjusted, and comprise the period 1947:1-2007:4.

Debt

Debt corresponds to the Federal government debt held by the public. The source is the Federal Reserve Bank of St Louis (series "FYGFDPUN"). Data are quarterly, seasonally adjusted, and comprise the period 1970:1-2007:4.

Average Cost of Financing Debt

The average cost of financing debt is obtained by dividing net interest payments by debt at time $t-1$.

Long-Term Interest Rate

Long-Term Interest Rate corresponds to the yield to maturity of 10-year government securities. Data are quarterly, and comprise the period 1960:1-2007:4. The source is the OECD, Main Economic Indicators (series "USA.IRLTLT01.ST").

\section{C.2 U.K. Data}

Housing Prices

Housing prices are measured using two sources: (a) the Mix-Adjusted House Price Index (Feb $2002=100)$ provided by the Office of the Deputy Prime Minister (ODPM), seasonally adjusted, and available for the period 1968:2-2007:4; and (b) the All-Houses Price Index (1952Q4 = 100 and 1993Q1=100) computed by the Nationwide Building Society, which we seasonally adjust using Census X12 ARIMA, and is available for the period 1952:4-2007:4.

\section{GDP}

Data for GDP are quarterly, seasonally adjusted, and comprise the period 1955:12007:4. The source is the Office for National Statistics, Release UKEA, Table A1 (series "YBHA").

\section{Consumption}

The source is the Office for National Statistics, Release CT, Tables 0.GS.CS, SER.CS and NDG.CS. Consumption is defined as the expenditure in non-durable consumption goods and services excluding housing services, actual rentals paid by tenants and imputed rentals for housing, i.e. UTIJ-[LLKE-(UTZI+ZWUQ)]+UTIN-(BMBT-GBFJ), where: "UTIJ" is expenditure in non-durable goods, "LLKE" is expenditure in housing, water, electricity, gas and other fuels, "UTZI" is expenditure in water supply, "ZWUZQ" is expenditure in electricity, gas and other fuels, "UTIN" is expenditure in consumption services, "BMBT" is expenditure in actual rentals paid by tenants, and "GBFJ" is expenditure in imputed rentals for housing. Data are quarterly, seasonally adjusted, and comprise the period 1963:1-2007:4.

Price Deflator

All variables were deflated by the GDP deflator. Data are quarterly, seasonally adjusted, and comprise the period 1955:1-2007:4. The source is the Office for National Statistics, Release MDS, Table 1.1 (series "YBGB"). 
Investment

The source is the Office for National Statistics, Release MD (Table 1.10) and Release ETAS (Table 2.7). Investment is defined as total gross fixed capital formation (series "NPQX") excluding gross fixed capital formation in dwellings by private sector (series "DFDF") and gross fixed capital formation by general government (series "NNBF"). Data are quarterly, seasonally adjusted, and comprise the period 1955:1-2007:4.

Wages

Wages correspond to U.K. average monthly wages $(2000=100)$. Data are quarterly, seasonally adjusted, and comprise the period 1963:1-2007:4. The source is Datastream, based on IMF, International Financial Statistics.

Productivity

The source is the Office for National Statistics, Release PRDY (Table 1) and Release MDS (Table 7.2). Productivity is defined as the Index of Output per worker of the whole economy $(2003=100)$ (series "A4YM"). Data are quarterly, seasonally adjusted, and comprise the period 1959:3-2007:4.

Profits

The source is the Office for National Statistics, Release UKEA, Tables X1 and X8. Profits are defined as the sum of gross trading profits of private non-financial corporations both non UKs (series "CAED") and UK continental shelf companies (series "CAGD") and financial corporations (series "RITQ"). Data are quarterly, seasonally adjusted, and comprise the period 1955:1-2007:4.

Monetary Aggregate

The source is the Office for National Statistics, Release MD, Table 17.5. Monetary Aggregate corresponds to: (a) $\mathrm{M}_{2}$ (series "VQWU"); and (b) $\mathrm{M}_{4}$ (series "AUYN"). Data are quarterly, seasonally adjusted, and comprise the periods 1982:3-2007:4 (for $\mathrm{M}_{2}$ ) and 1963:1-2007:4 (for $\mathrm{M}_{4}$ ).

Stock Market Index

Stock Market Index corresponds to the FTSE-All Shares Index (1962:2=100 or 1962 April=100). Data are quarterly, and comprise the period 1962:2-2007:4. The source is Datastream.

Exchange Rate

The source is the Bank for International Settlements (BIS). Exchange Rate corresponds to real effective exchange rate (series "RNGB"). Data are quarterly (computed from monthly series by using end-of-period values), and comprise the period 1964:1-2007:4.

Government Spending

The source is the Office for National Statistics (ONS), Release Public Sector Accounts. Government Spending is defined as total current expenditures of the Public Sector ESA 95 (series "ANLT") less net investment (series "ANNW"), to which we subtract net interest payments (obtained as the difference between interest and dividends paid to private sector (series "ANLO") and interest and dividends received from the private sector and the Rest of World (series "ANBQ"). We seasonally adjust quarterly data using Census X12 ARIMA, and the series comprise the period 1947:1-2007:4. 


\section{Government Revenue}

The source is the Office for National Statistics (ONS), Release Public Sector Accounts. Government Revenue is defined as total current receipts of the Public Sector ESA 95 (series "ANBT"). We seasonally adjust quarterly data using Census X12 ARIMA, and the series comprise the period 1947:1-2007:4.

Debt

The source is the Office for National Statistics (ONS), Release Public Sector Accounts. Debt is defined as the Public Sector net debt (series "BKQK"). We seasonally adjust quarterly data using Census X12 ARIMA, and the series comprise the period 1962:42007:4.

\section{Average Cost of Financing Debt}

The average cost of financing debt is obtained by dividing net interest payments by debt at time $t-1$.

Long-Term Interest Rate

Long-Term Interest Rate corresponds to the yield to maturity of 10-year government securities. Data are quarterly, and comprise the period 1957:1-2007:4. The source is the IMF, International Financial Statistics (series "61...ZF").

\section{C.3 Germany Data}

Housing Prices

Housing prices correspond to the residential property price index. Data are quarterly, seasonally adjusted, and available for the period 1970:1-2006:4. The source is the Bank for International Settlements (BIS).

\section{GDP}

Data for GDP are quarterly, seasonally adjusted, and comprise the period 1960:12007:4. The source is the IMF, International Financial Statistics (series "IFS.Q.134.9.9B.B\$C.Z.F.\$\$").

\section{Consumption}

The source is the IMF, International Financial Statistics (series "IFS.Q.134.9.96.F\$C.Z.W.\$\$"). Consumption is defined as the private consumption or household consumption expenditure including non-profitable institutions serving households. Data are quarterly, seasonally adjusted, and comprise the period 1960:12007:4.

Price Deflator

All variables were deflated by the GDP deflator $(2000=100)$. Data are quarterly, seasonally adjusted, and comprise the period 1960:1-2007:2. The source is the IMF, International Financial Statistics (series "IFS.Q.134.9.9B.BIR.Z.F.\$\$").

Investment

The source is the IMF, International Financial Statistics. Investment is defined as total gross fixed capital formation (series "IFS.Q.134.9.94.E\$C.Z.F.\$\$"). Data are quarterly, seasonally adjusted, and comprise the period 1960:1-2007:4. 
Wages

The source is the OECD, Main Economic Indicators. Wages are defined as the index of hourly earnings in manufacturing (series "MEI.Q.DEU.LCEAMN01.IXOBSA"). Data are quarterly, seasonally adjusted, and comprise the period 1960:1-2006:4.

Productivity

The source is the OECD, Economic Outlook. Productivity is defined as: the West Germany labour productivity of the total economy index (series "OEO.Q.WGR.PDTY"), for the period 1970:1990:4; the Germany labour productivity of the total economy (series "OEO.Q.DEU.PDTY"), for the period 1992:1-2007:4; and the simple average of the two previous indexes, for the period 1991:1-1991:4. Data are quarterly, and seasonally adjusted.

Monetary Aggregate

The sources are the IMF, International Financial Statistics, and the European Central Bank (ECB). Monetary Aggregate corresponds to: (a) $\mathrm{M}_{2}$ (series "34..XZF"); or (bi) M1 (adjusted notional stock); (bii) $\mathrm{M}_{2}$ (adjusted notional stock); (biii) $\mathrm{M}_{3}$ (adjusted notional stock). Data are quarterly, seasonally adjusted, and comprise, respectively, the periods: (a) 1958:1-1998:4; (bi) 1980:1-2007:4; (bii) 1980:1-2007:4; and (biii) 1970:1-2007:4.

Stock Market Index

Stock Market Index corresponds to the MSCI-Gross Return Index (1969:4=100). Data are quarterly, and comprise the period 1969:4-2007:4. The source is Morgan Stanley Capital International.

\section{Exchange Rate}

The source is the OECD, Main Economic Indicators. Exchange Rate corresponds to real effective exchange rate (series "MEI.Q.DEU.CCRETT01.IXOB"). Data are quarterly, and comprise the period 1970:1-2007:4.

\section{Government Spending}

The source is the Bundesbank and the Monthly Reports released by the German Ministry of Finance. Government Spending is defined as Central Government total expenditure (on a cash basis). We seasonally adjust quarterly data using Census X12 ARIMA, and the series comprise the period 1979:1-2007:3.

\section{Government Revenue}

The source is the Bundesbank and the Monthly Reports released by the German Ministry of Finance. Government Revenue is defined as Central Government total revenue (on a cash basis). We seasonally adjust quarterly data using Census X12 ARIMA, and the series comprise the period 1979:1-2007:3.

Debt

The source is the Bundesbank and the Monthly Reports released by the German Ministry of Finance. Debt is as the Central, state and local government debt (excluding hospitals). We seasonally adjust quarterly data using Census X12 ARIMA, and the series comprise the period 1966:4-2007:4. 
Average Cost of Financing Debt

The average cost of financing debt is obtained by dividing net interest payments by debt at time $t-1$.

Long-Term Interest Rate

Long-Term Interest Rate corresponds to the yield to maturity of 10-year government securities. Data are quarterly, and comprise the period 1957:1-2007:4. The source is the IMF, International Financial Statistics (series "61...ZF").

\section{C.4 Italy Data}

Housing Prices

Housing prices correspond to the residential property price index. Data are quarterly, seasonally adjusted, and available for the period 1970:1-2006:4. The source is the Bank for International Settlements (BIS).

GDP

Data for GDP are quarterly, seasonally adjusted, and comprise the period 1960:1-20073. The source is the IMF, International Financial Statistics (series "IFS.Q.136.9.9B.B\$C.Z.F.\$\$").

Consumption

The source is the IMF, International Financial Statistics (series "IFS.Q.136.9.96.F\$C.Z.W.\$\$"). Consumption is defined as the private consumption or household consumption expenditure including non-profitable institutions serving households. Data are quarterly, seasonally adjusted, and comprise the period 1970:12007:3.

Price Deflator

All variables were deflated by the GDP deflator $(2000=100)$. Data are quarterly, seasonally adjusted, and comprise the period 1980:1-2007:2. The source is the IMF, International Financial Statistics (series “IFS.Q.136.9.9B.BIR.Z.F.\$\$\$).

Investment

The source is the IMF, International Financial Statistics. Investment is defined as total gross fixed capital formation (series "IFS.Q.136.9.94.E\$C.Z.W.\$\$"). Data are quarterly, seasonally adjusted, and comprise the period 1960:1-2007:3.

\section{Wages}

The source is the OECD, Main Economic Indicators. Wages are defined as the index of hourly wage rate index in industry including construction (series "MEI.Q.ITA.LCEAMN01.IX"). Data are quarterly, seasonally adjusted, and comprise the period 1960:1-2006:4.

\section{Productivity}

The source is the OECD, Economic Outlook. Productivity is defined as the Italy labour productivity of the total economy index (series "OEO.Q.ITA.PDTY. Data are quarterly, and seasonally adjusted, and comprise the period 1970:1-2007:4. 


\section{Monetary Aggregate}

The sources are the IMF, International Financial Statistics, and the European Central Bank (ECB). Monetary Aggregate corresponds to: (a) $\mathrm{M}_{2}$ (series "34..XZ"); or (bi) M1 (adjusted notional stock); (bii) $\mathrm{M}_{2}$ (adjusted notional stock); (biii) $\mathrm{M}_{3}$ (adjusted notional stock). Data are quarterly, seasonally adjusted, and comprise, respectively, the periods: (a) 1963:1-1998:4; (bi) 1980:1-2007:4; (bii) 1980:1-2007:4; and (biii) 1970:1-2007:4.

\section{Stock Market Index}

Stock Market Index corresponds to the MSCI-Gross Return Index (1969:4=100). Data are quarterly, and comprise the period 1969:4-2007:4. The source is Morgan Stanley Capital International.

\section{Exchange Rate}

The source is the OECD, Main Economic Indicators. Exchange Rate corresponds to real effective exchange rate (series "MEI.Q.ITA.CCRETT01.IXOB"). Data are quarterly, and comprise the period 1970:1-2007:4.

\section{Government Spending}

The source is the Bank of Italy and the Italian Ministry of Finance. Government Spending is defined as Central Government total expenditure (on a cash basis). We seasonally adjust quarterly data using Census X12 ARIMA, and the series comprise the period 1960:1-2007:4.

Government Spending

The source is the Bank of Italy and the Italian Ministry of Finance. Government Spending is defined as Central Government primary expenditure (on a cash basis). We seasonally adjust quarterly data using Census X12 ARIMA, and the series comprise the period 1960:1-2007:4.

\section{Government Revenue}

The source is the Bank of Italy and the Italian Ministry of Finance. Government Revenue is defined as Central Government total revenue (on a cash basis). We seasonally adjust quarterly data using Census X12 ARIMA, and the series comprise the period 1960:1-2007:4.

Debt

The source is the Bank of Italy. Debt is as the stock of General Government short-term ("S571730M"), and medium and long-term securities ("S605216M"). We seasonally adjust quarterly data using Census X12 ARIMA, and the series comprise the period 1984:4-2007:4.

Average Cost of Financing Debt

The average cost of financing debt is obtained by dividing net interest payments by debt at time $t-1$.

Long-Term Interest Rate

Long-Term Interest Rate corresponds to the yield to maturity of 10-year government securities. Data are quarterly, and comprise the period 1957:1-2007:4. The source is the IMF, International Financial Statistics (series "61...ZF"). 
Figure 1 - Average cost of servicing debt and (annualized) nominal GDP growth.

U.S.

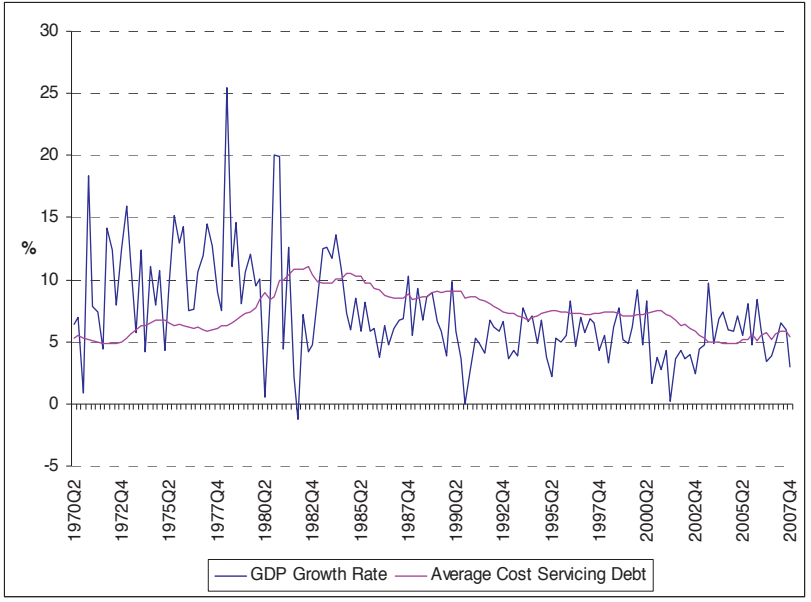

Germany, before the reunification

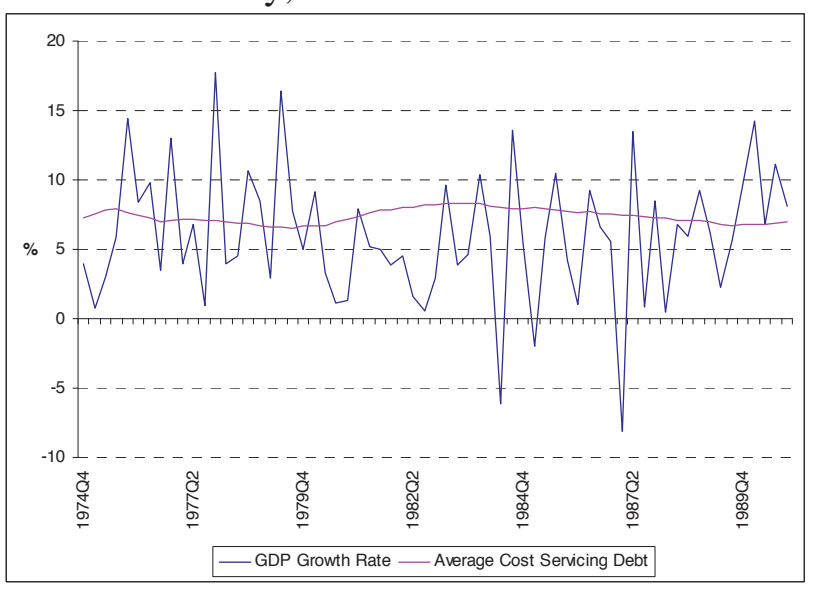

U.K.

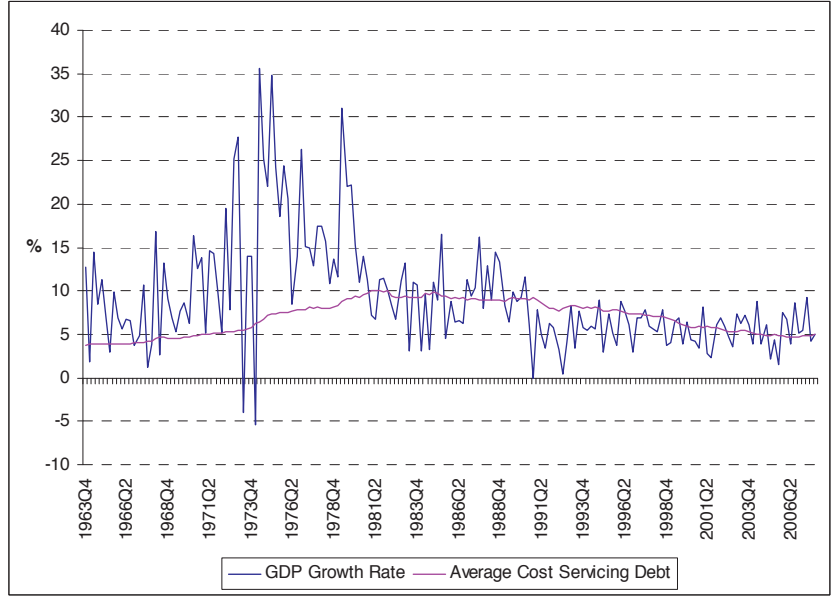

Germany, after the reunification

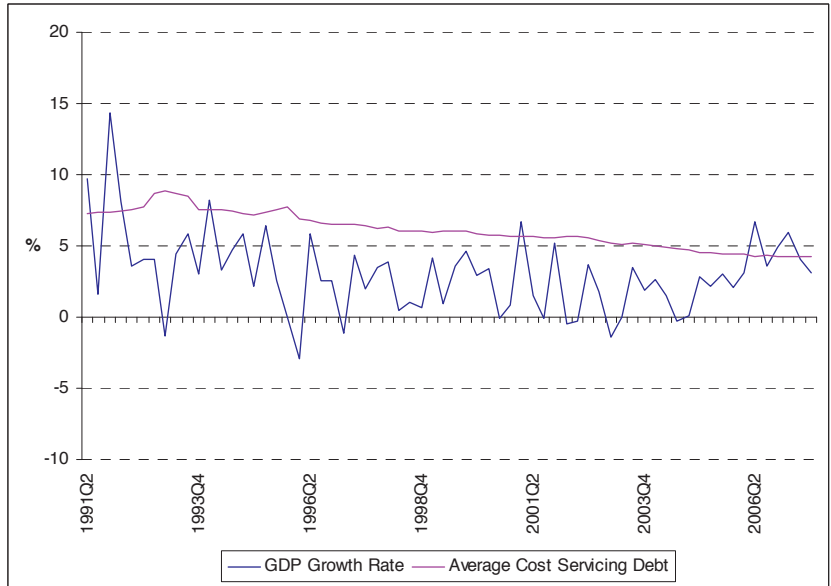

Italy

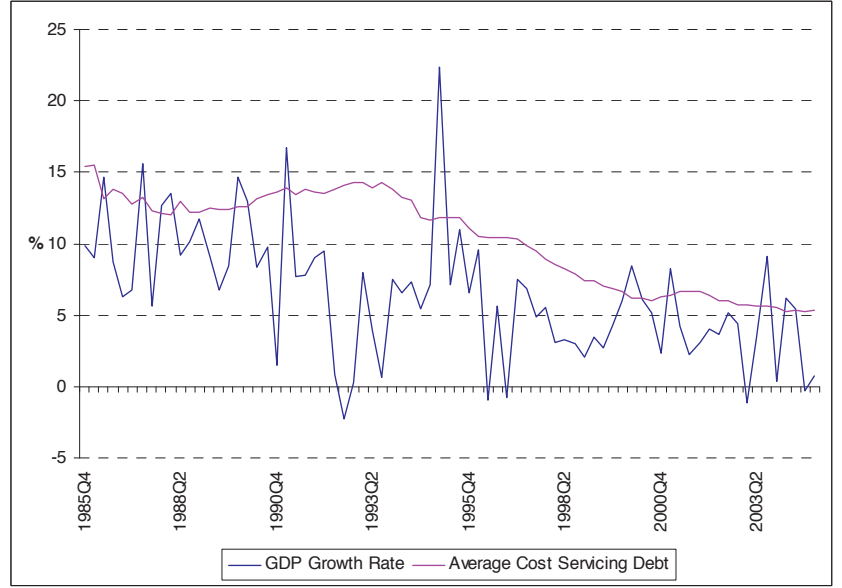


Figure 2 - Quarterly versus annual fiscal data, U.S..
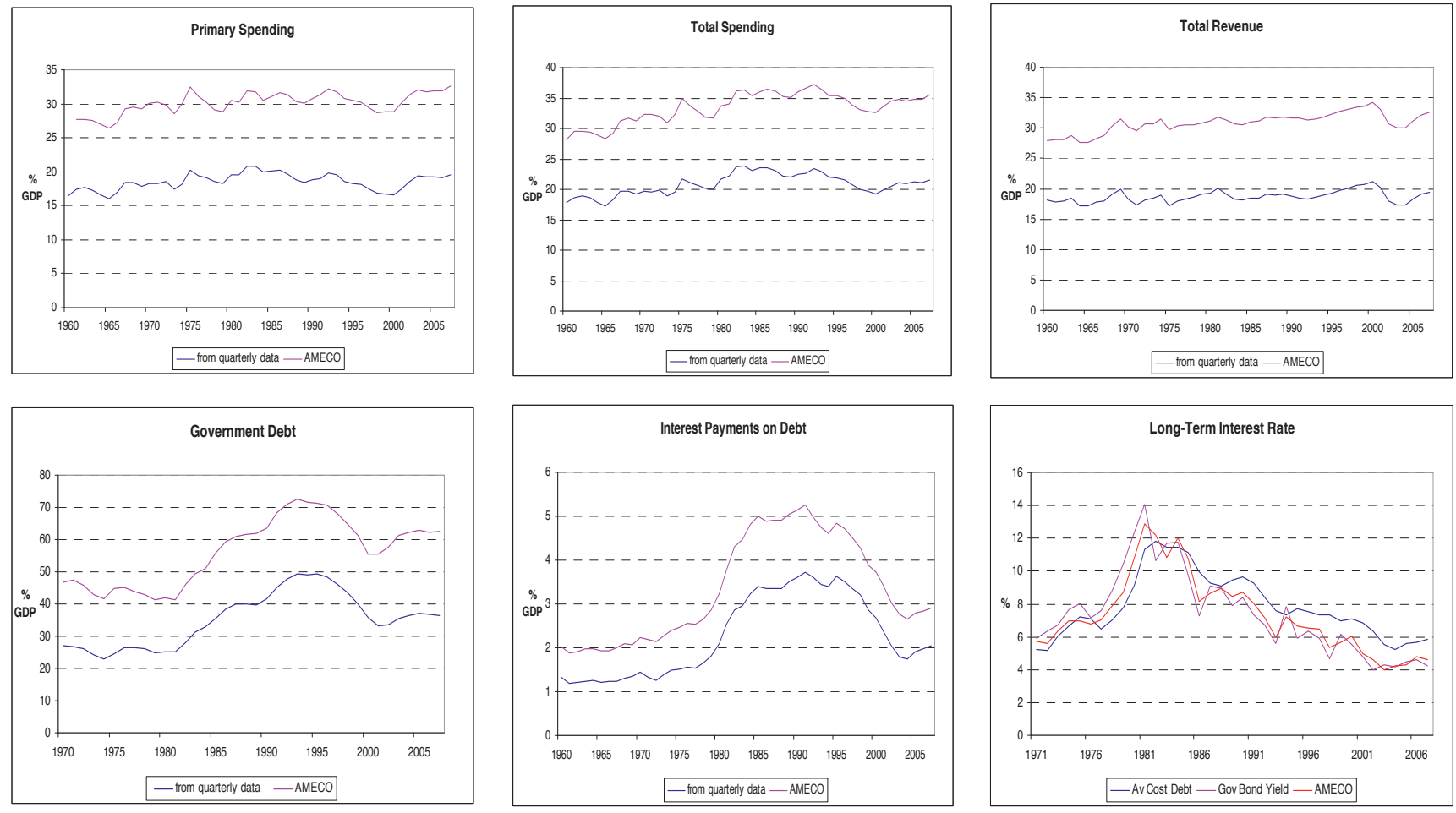

Figure 3 - Quarterly versus annual fiscal data, U.K..
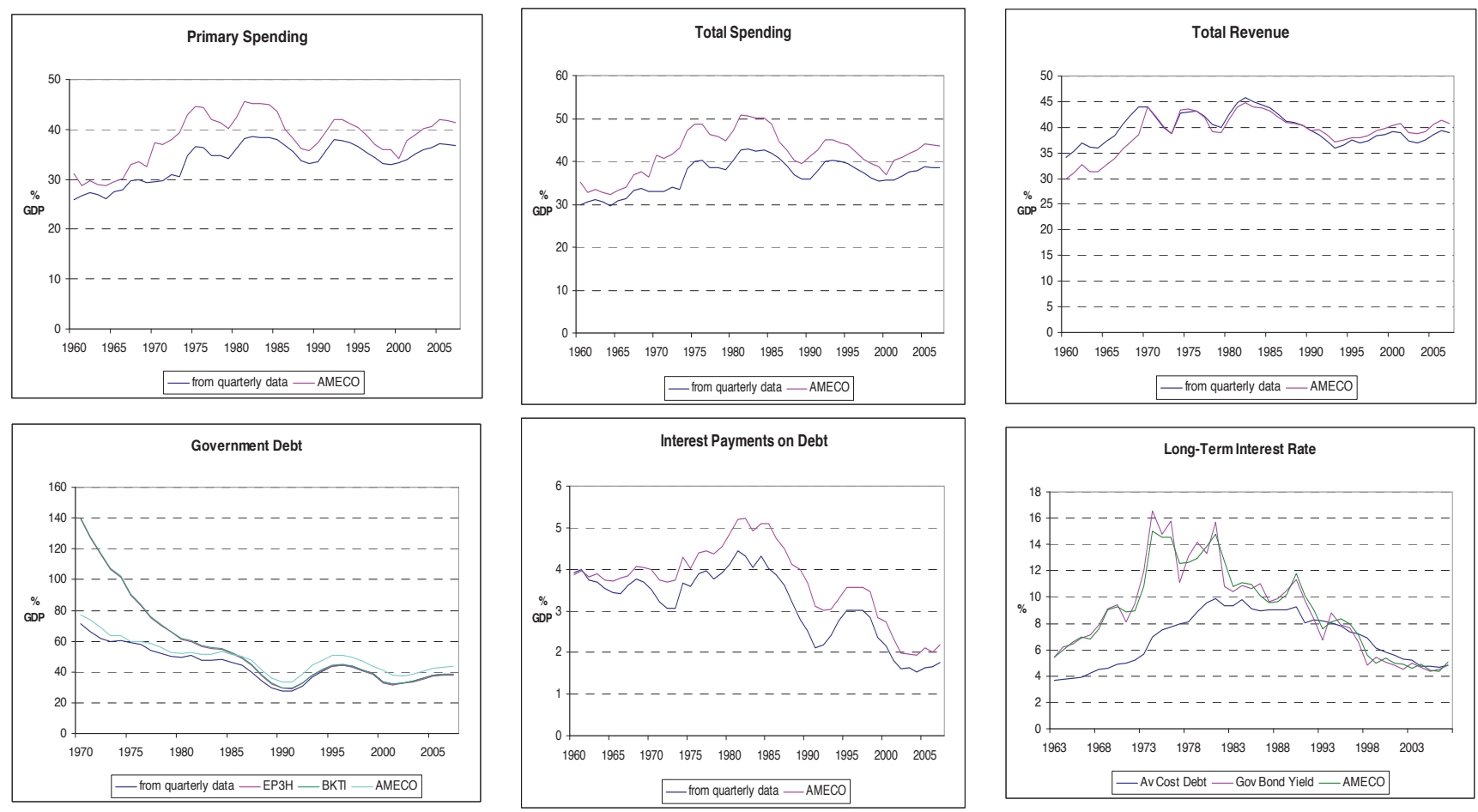

Notes: EP3H - 'Financial Intermediation Services Indirectly Measured (FISIM) adjusted GDP; BKTL GDP at current prices. 
Figure 4 - Quarterly versus annual fiscal data, Germany.
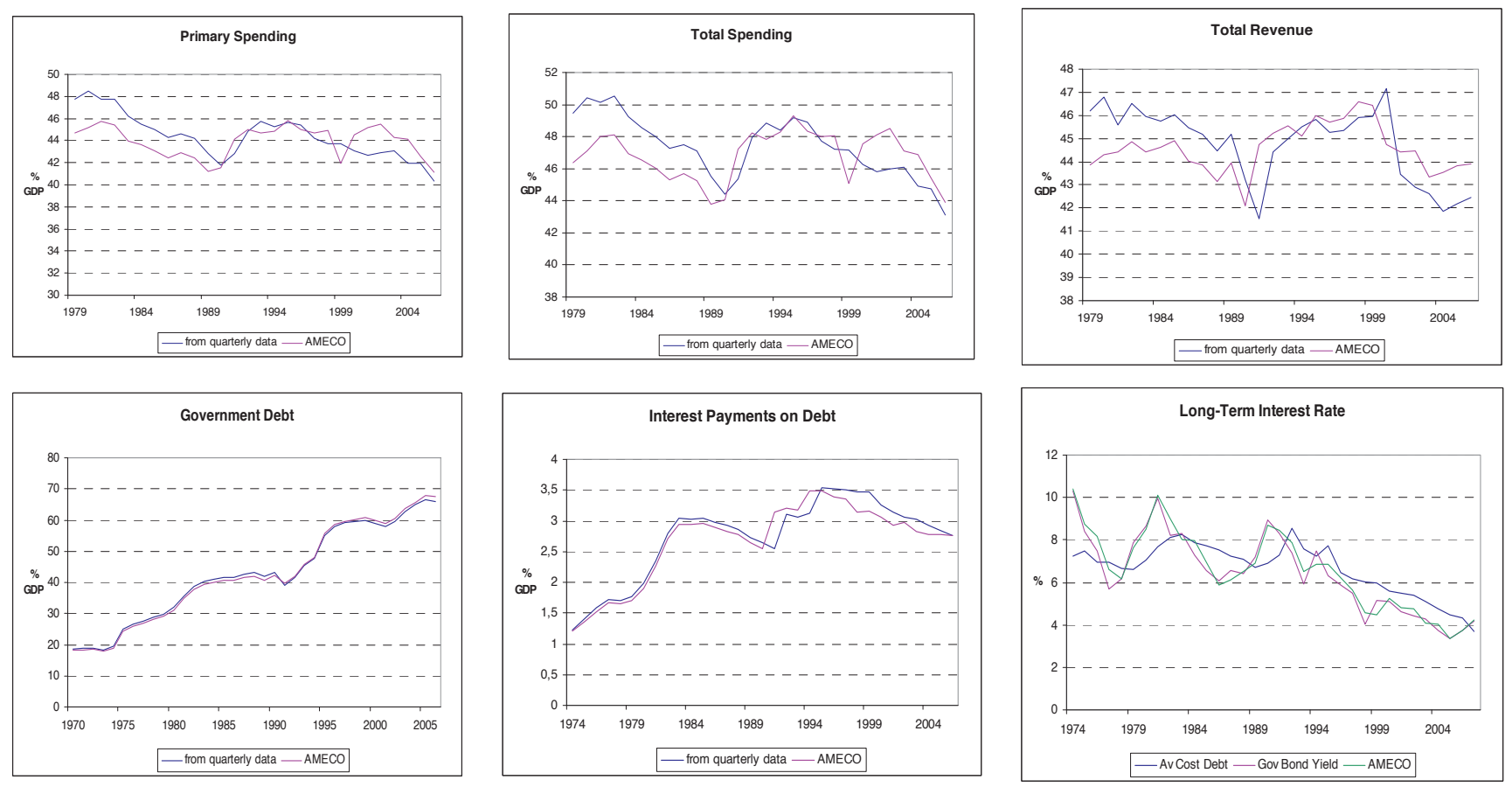

Figure 5 - Quarterly versus annual fiscal data, Italy.
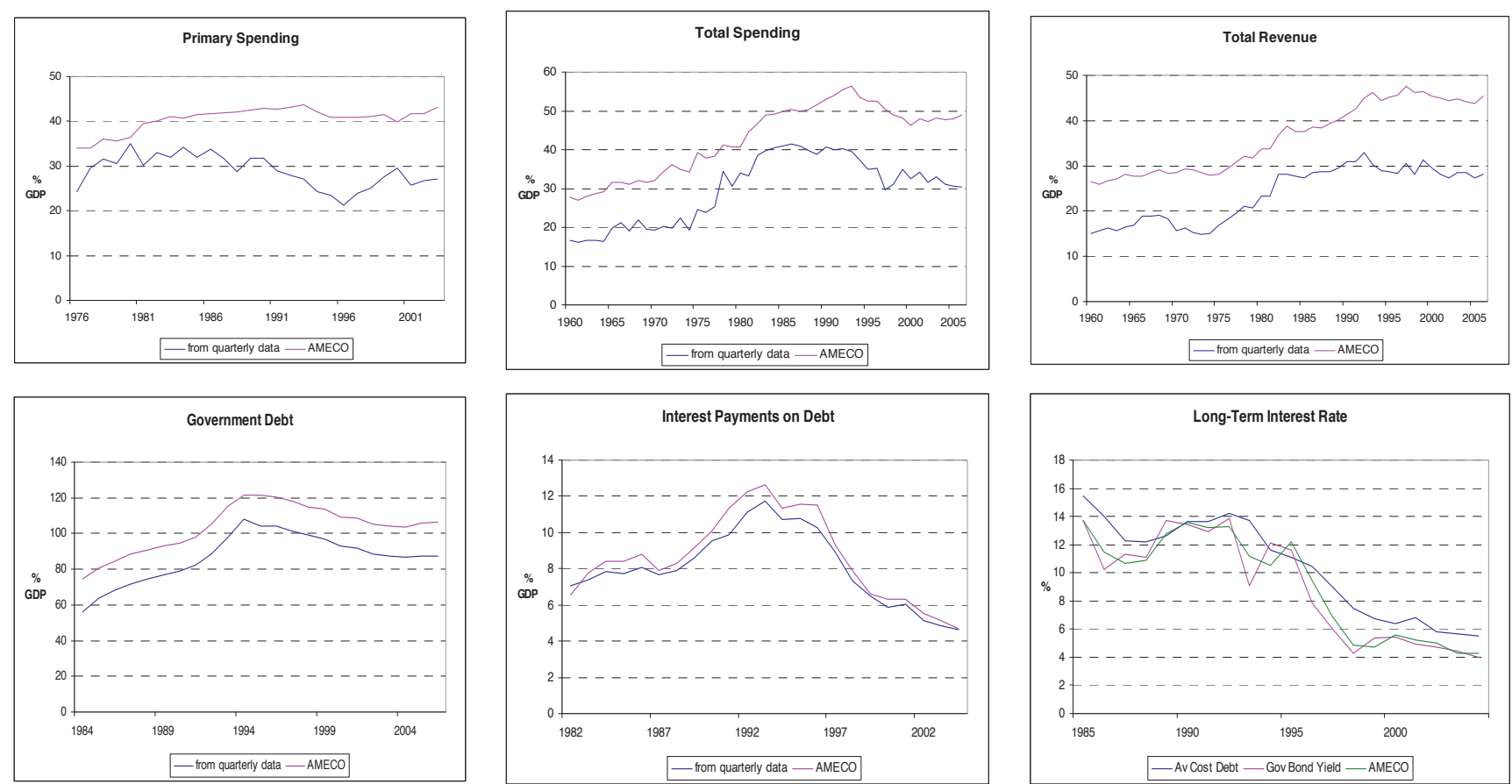
Figure 6 - Implicit debt ratio and observed debt ratio, percentage of GDP.

U.S.

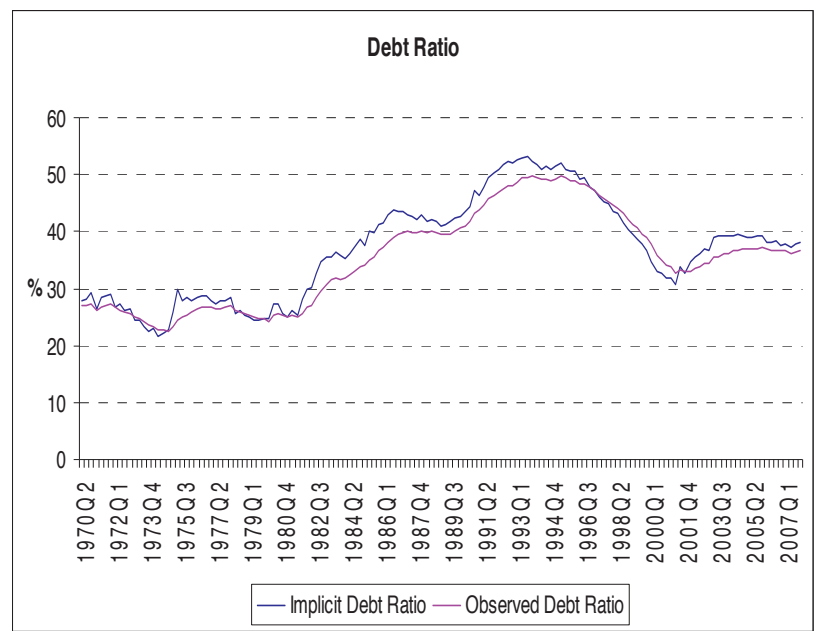

Germany

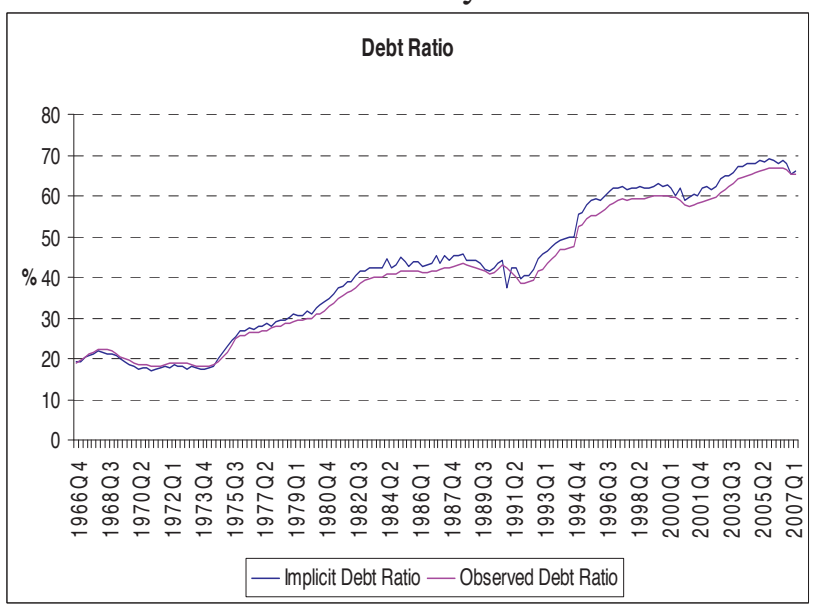

Note: Implicit debt ratio computed via equation (14)
U.K.

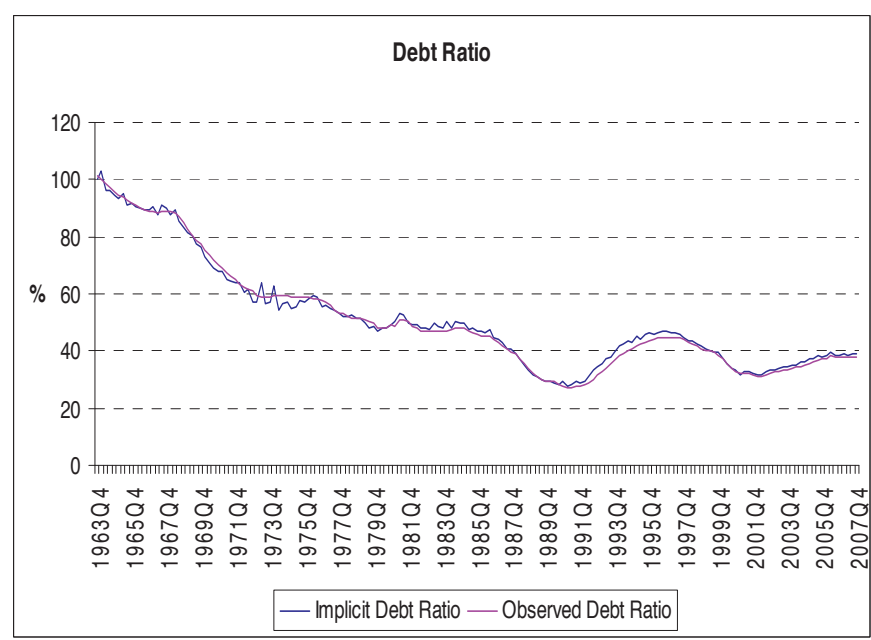

Italy

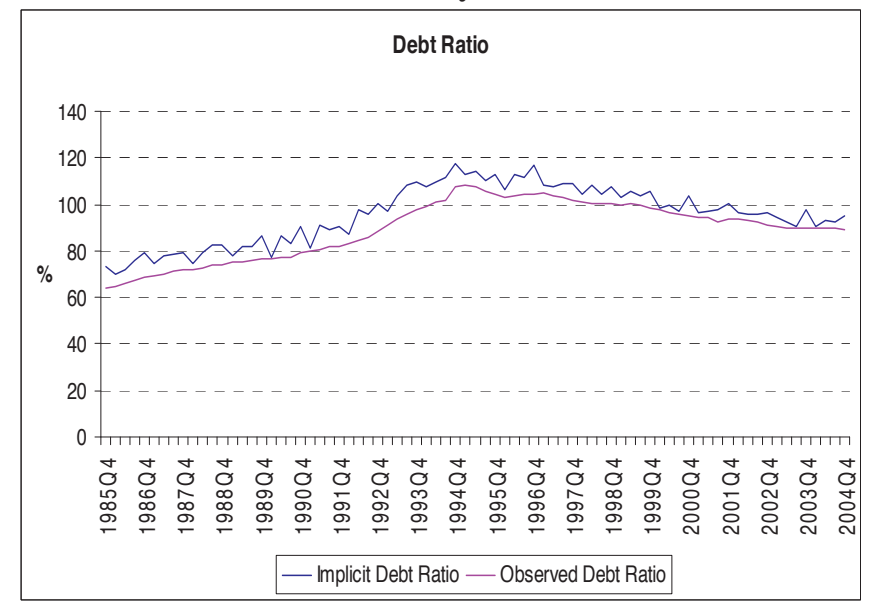




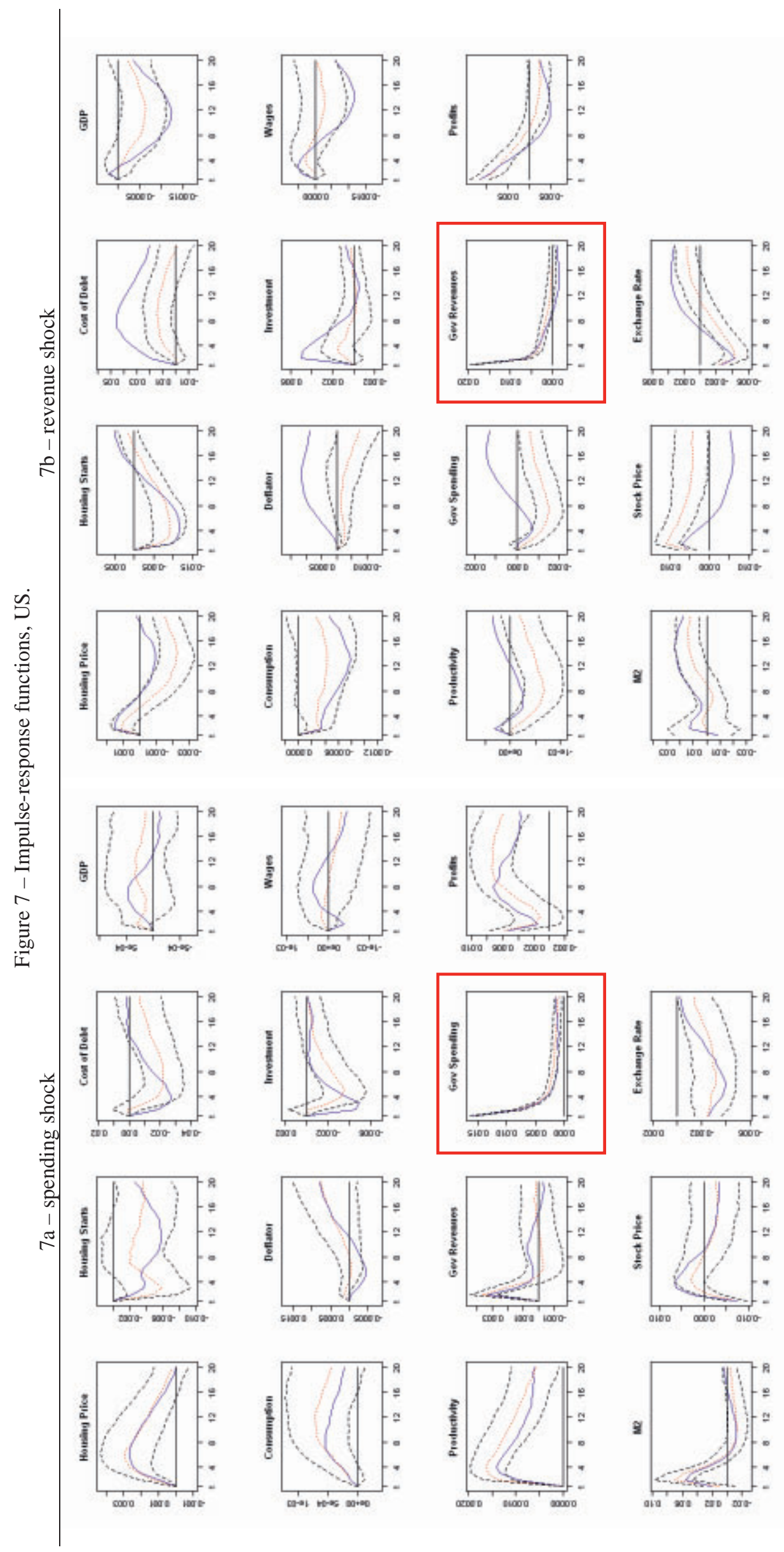




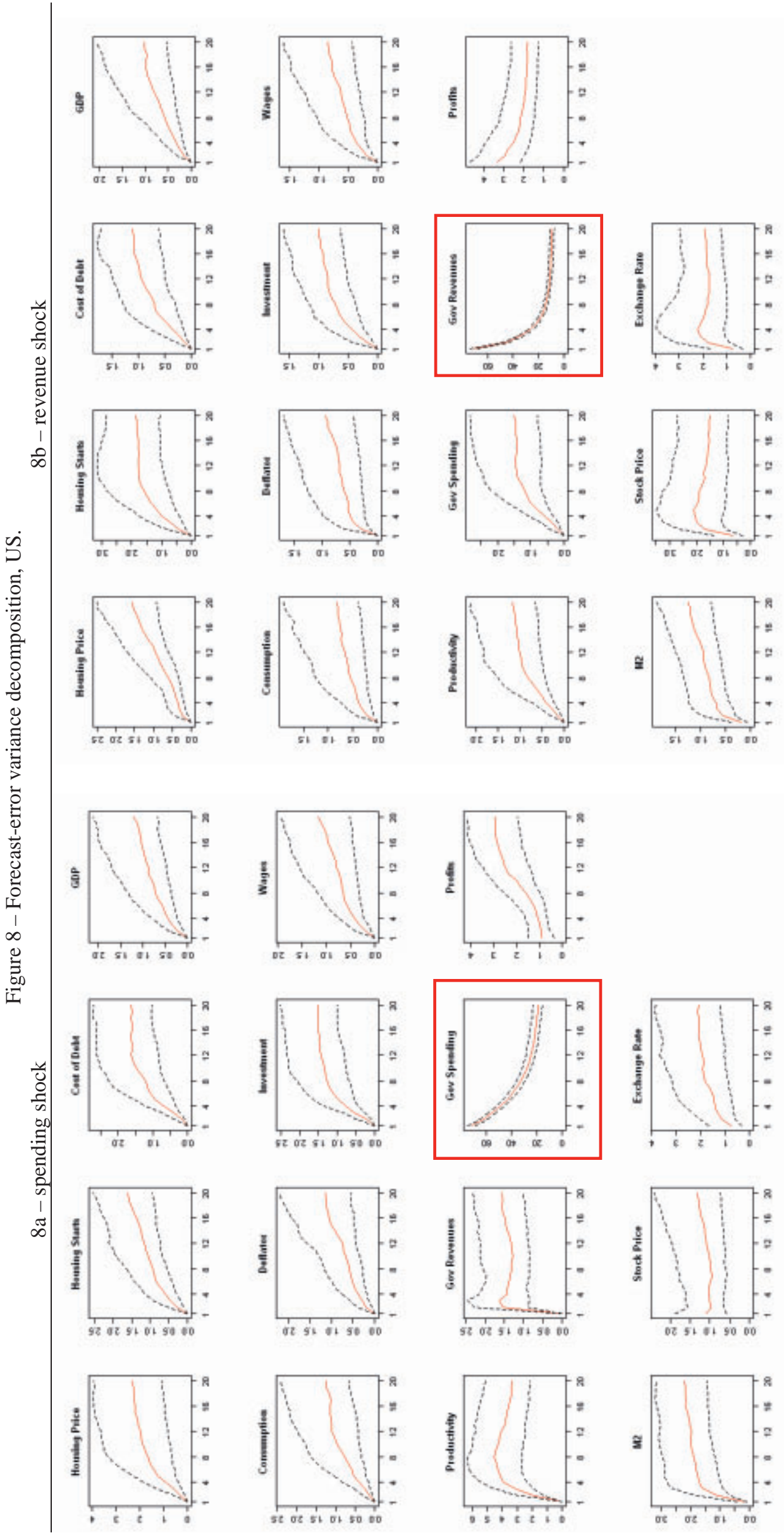




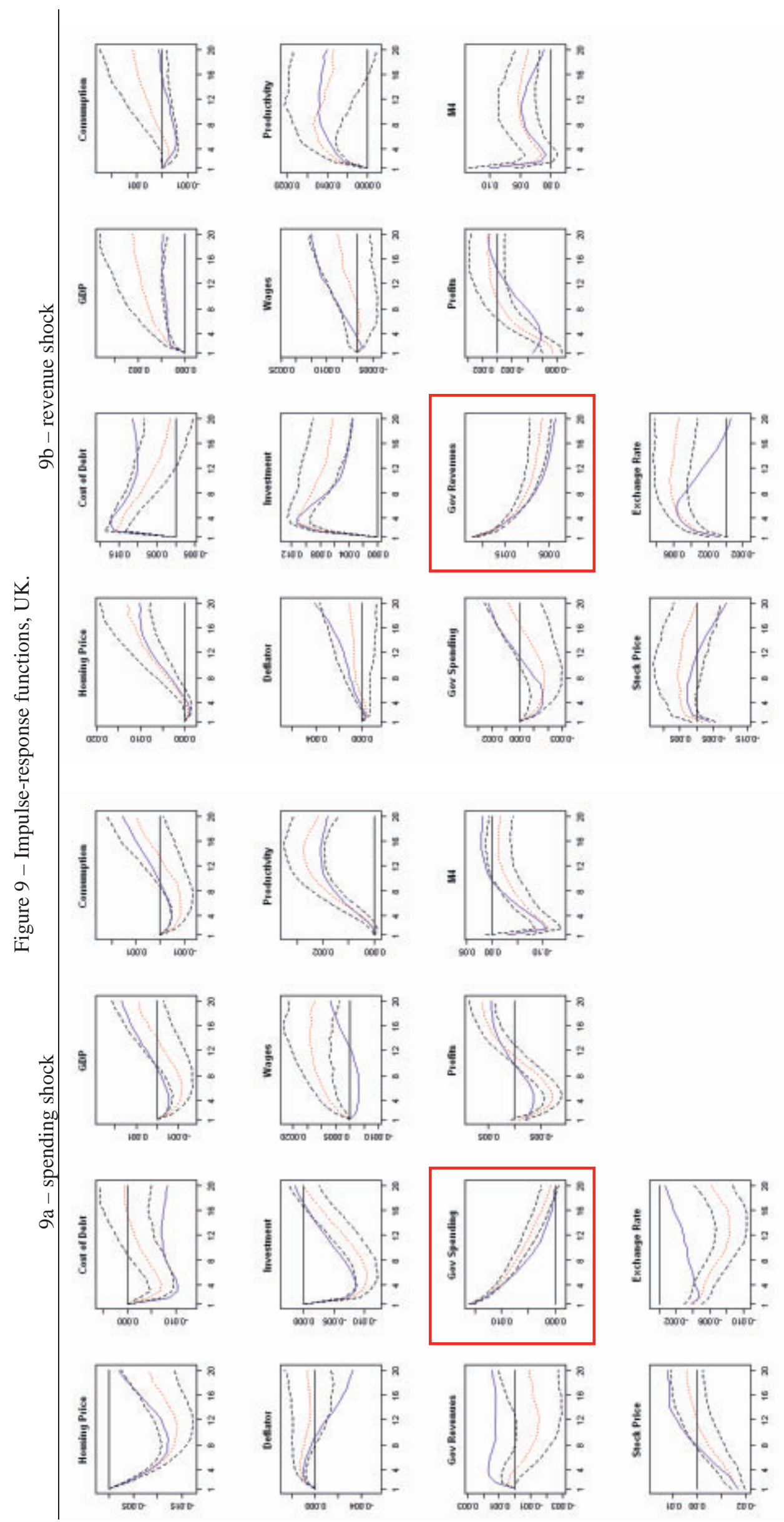




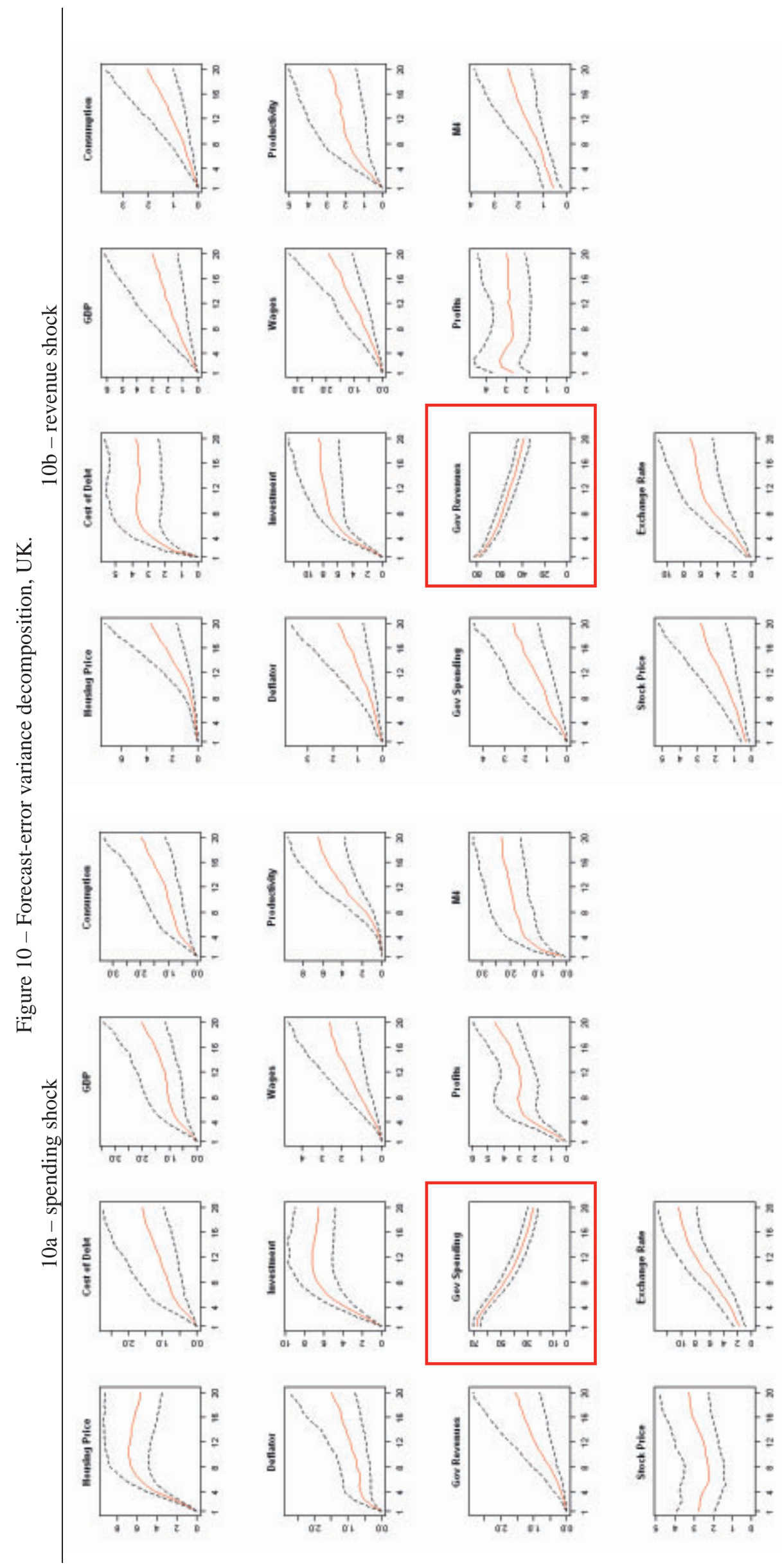




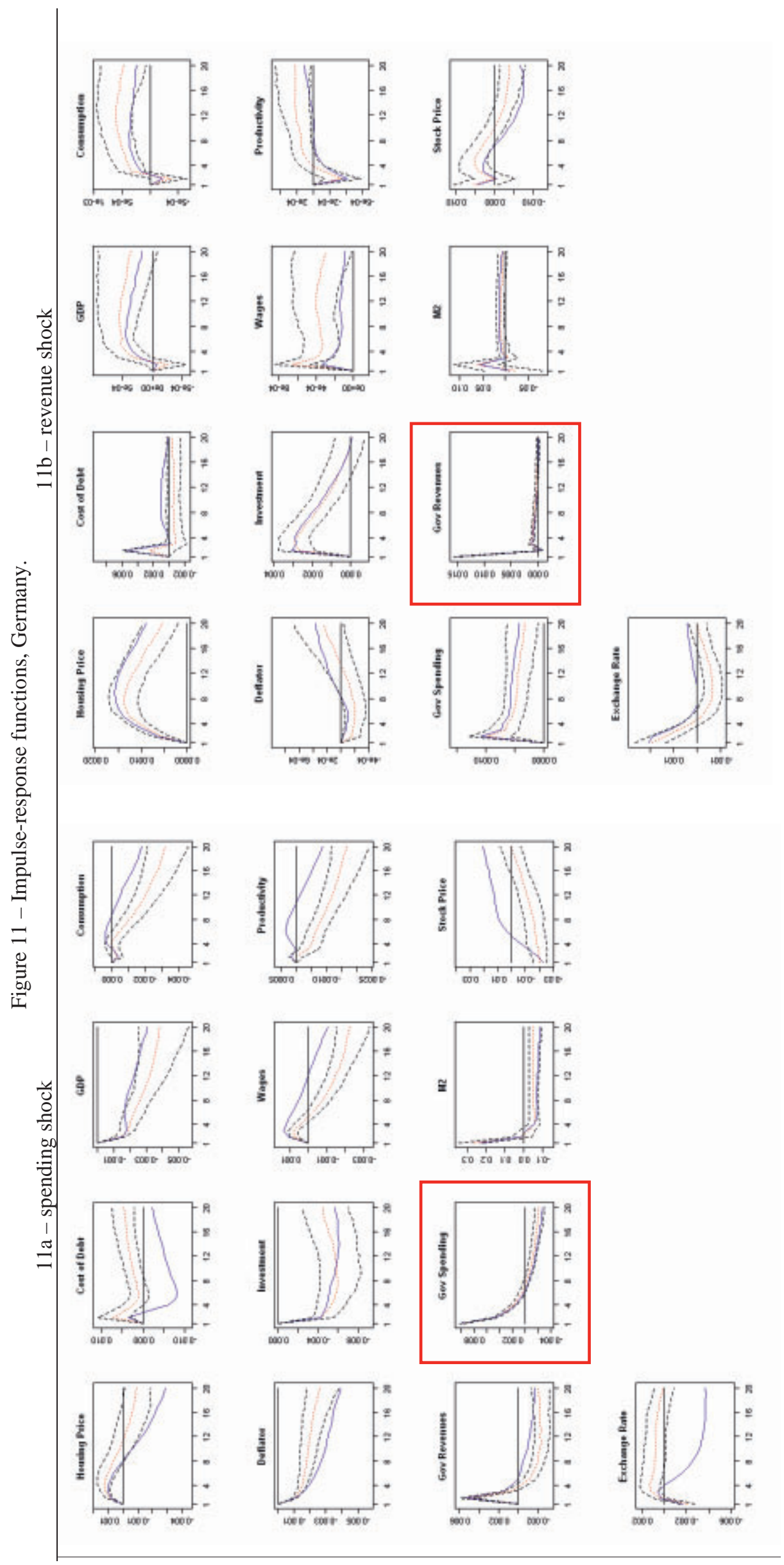




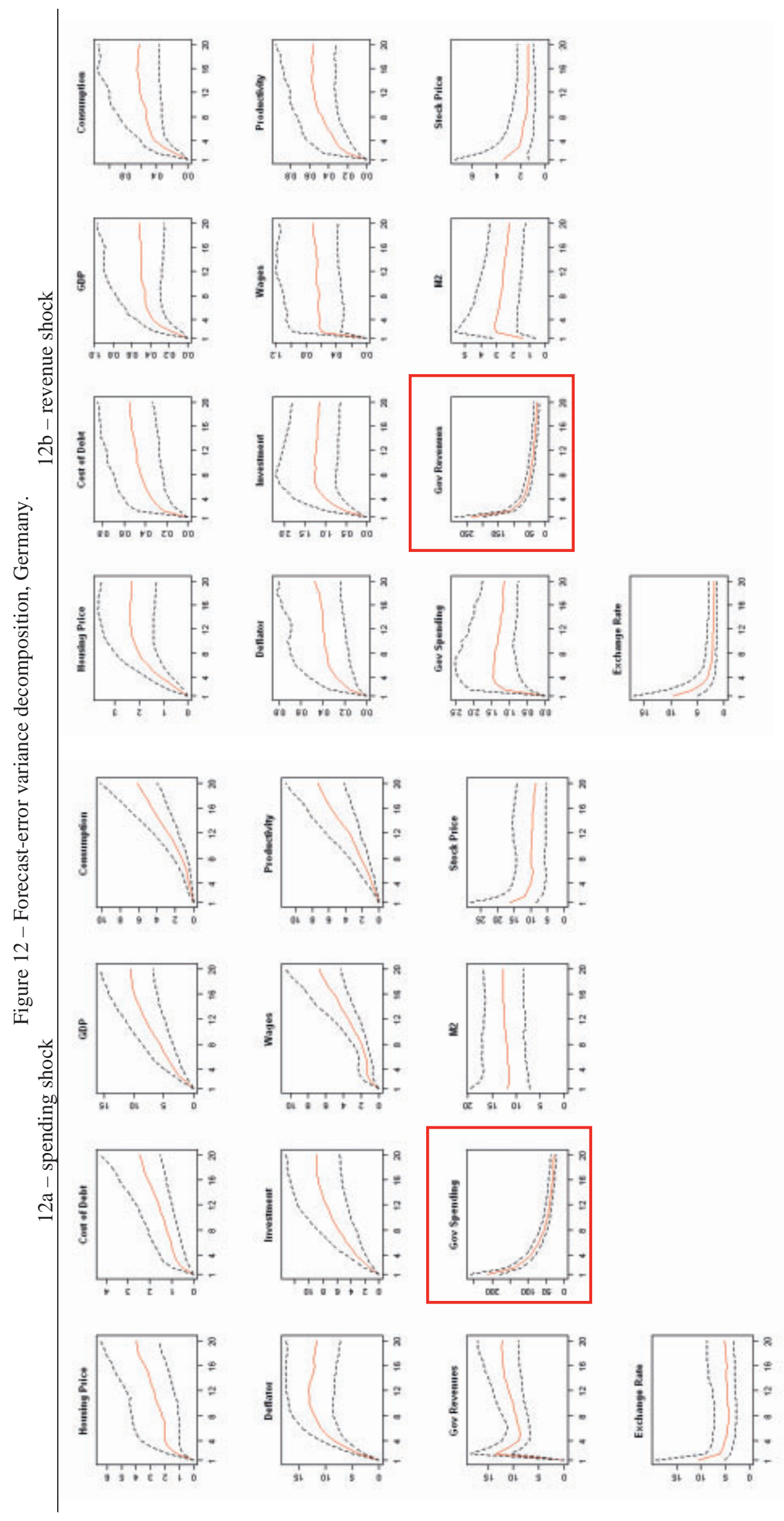




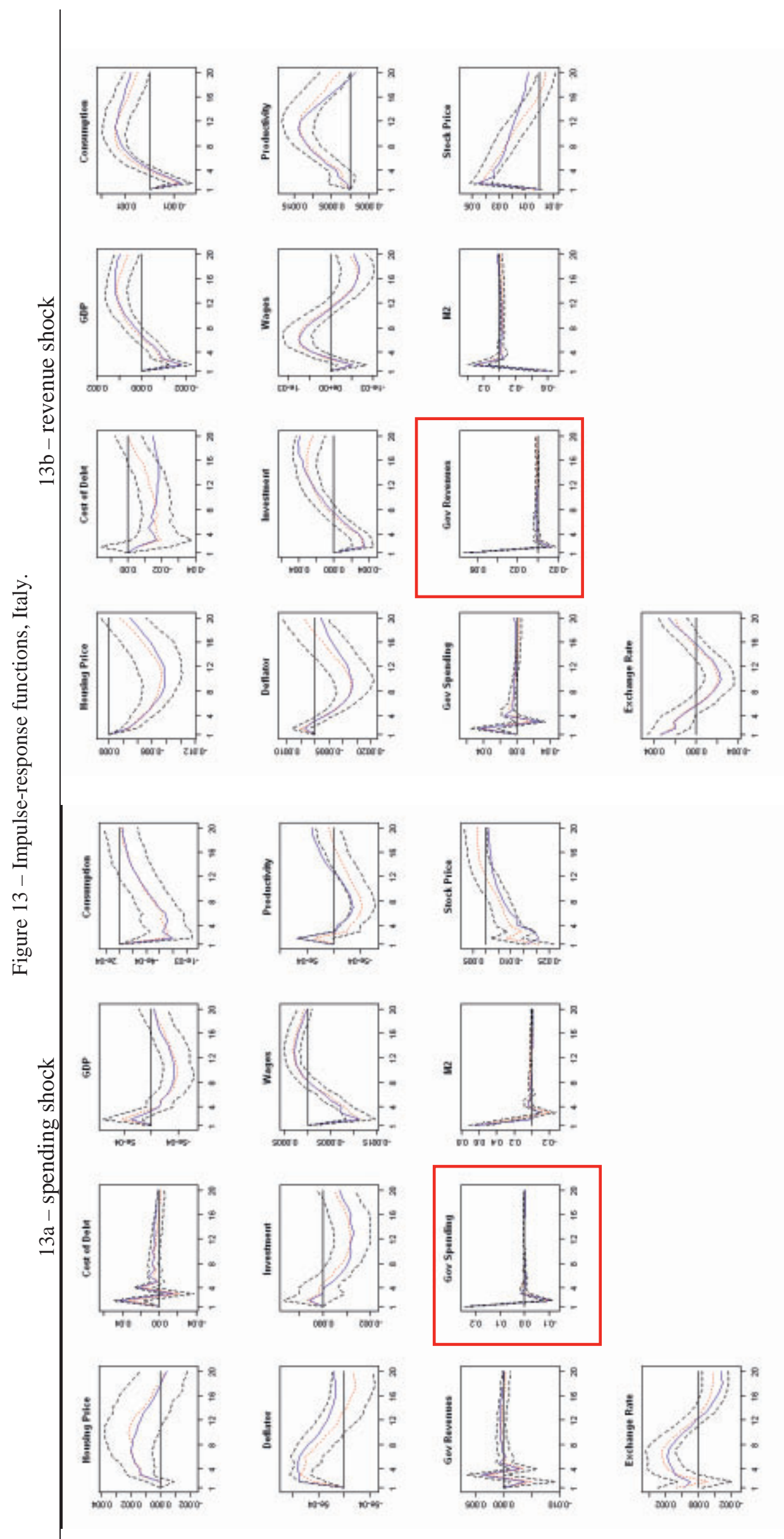




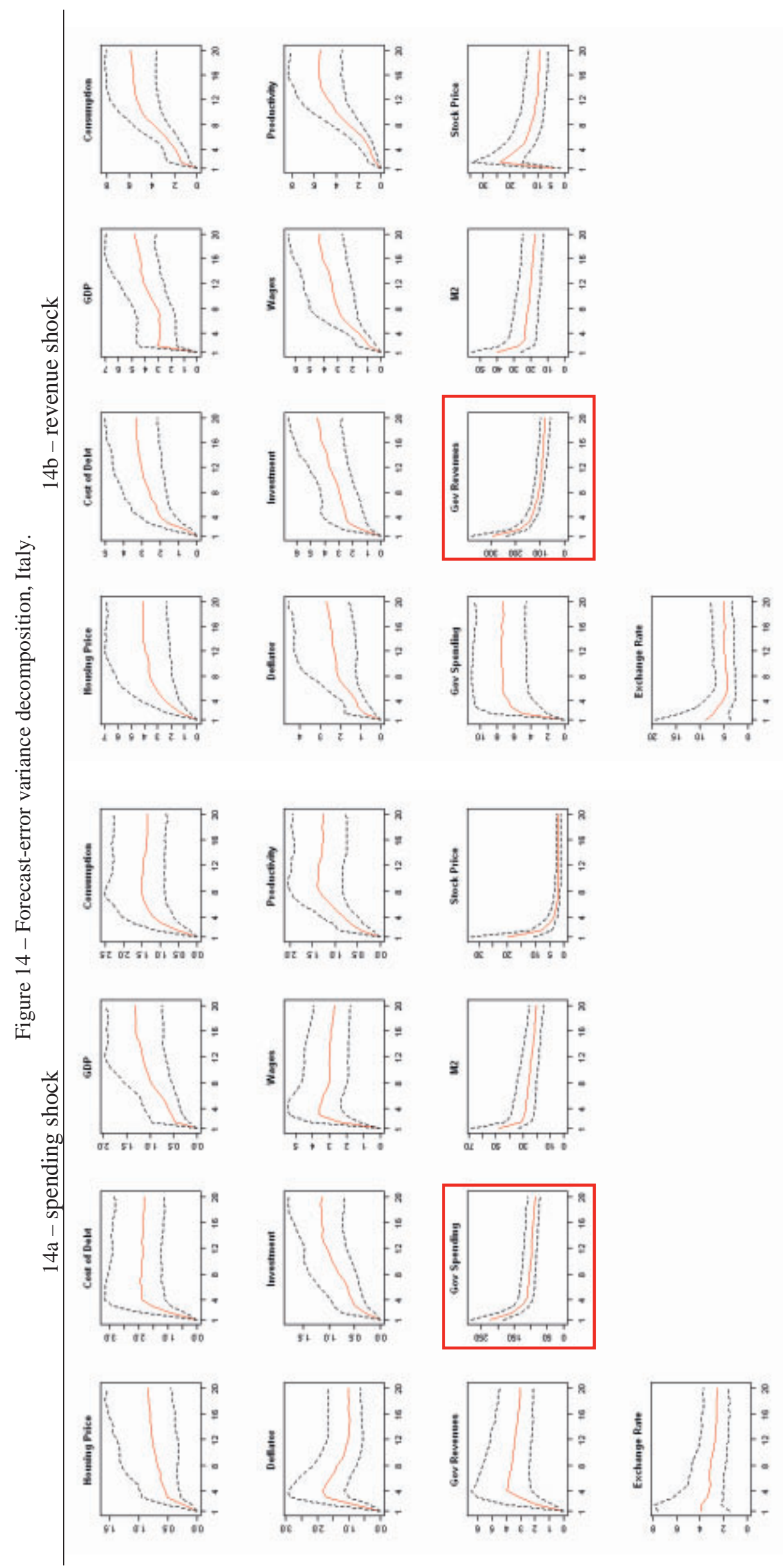




\section{European Central Bank Working Paper Series}

For a complete list of Working Papers published by the ECB, please visit the ECB's website (http://www.ecb.europa.eu).

944 "The New Area-Wide Model of the euro area: a micro-founded open-economy model for forecasting and policy analysis" by K. Christoffel, G. Coenen and A. Warne, October 2008.

945 "Wage and price dynamics in Portugal” by C. Robalo Marques, October 2008.

946 “Macroeconomic adjustment to monetary union” by G. Fagan and V. Gaspar, October 2008.

947 "Foreign-currency bonds: currency choice and the role of uncovered and covered interest parity" by M. M. Habib and M. Joy, October 2008.

948 "Clustering techniques applied to outlier detection of financial market series using a moving window filtering algorithm” by J. M. Puigvert Gutiérrez and J. Fortiana Gregori, October 2008.

949 "Short-term forecasts of euro area GDP growth" by E. Angelini, G. Camba-Méndez, D. Giannone, L. Reichlin and G. Rünstler, October 2008.

950 "Is forecasting with large models informative? Assessing the role of judgement in macroeconomic forecasts" by R. Mestre and P. McAdam, October 2008.

95I "Exchange rate pass-through in the global economy: the role of emerging market economies" by M. Bussière and T. Peltonen, October 2008.

952 "How successful is the G7 in managing exchange rates?" by M. Fratzscher, October 2008.

953 "Estimating and forecasting the euro area monthly national accounts from a dynamic factor model" by E. Angelini, M. Bańbura and G. Rünstler, October 2008.

954 “Fiscal policy responsiveness, persistence and discretion” by A. Afonso, L. Agnello and D. Furceri, October 2008.

955 “Monetary policy and stock market boom-bust cycles” by L. Christiano, C. llut, R. Motto and M. Rostagno, October 2008.

956 "The political economy under monetary union: has the euro made a difference?" by M. Fratzscher and L. Stracca, November 2008.

957 "Modeling autoregressive conditional skewness and kurtosis with multi-quantile CAViaR" by H. White, T.-H. Kim, and S. Manganelli, November 2008.

958 “Oil exporters: in search of an external anchor” by M. M. Habib and J. Stráský, November 2008.

959 “What drives U.S. current account fluctuations?” by A. Barnett and R. Straub, November 2008.

960 "On implications of micro price data for macro models" by B. Maćkowiak and F. Smets, November 2008.

961 "Budgetary and external imbalances relationship: a panel data diagnostic" by A. Afonso and C. Rault, November 2008.

962 "Optimal monetary policy and the transmission of oil-supply shocks to the euro area under rational expectations" by S. Adjemian and M. Darracq Pariès, November 2008. 
963 "Public and private sector wages: co-movement and causality" by A. Lamo, J. J. Pérez and L. Schuknecht, November 2008.

964 “Do firms provide wage insurance against shocks? Evidence from Hungary” by G. Kátay, November 2008.

965 “IMF lending and geopolitics” by J. Reynaud and J. Vauday, November 2008.

966 “Large Bayesian VARs” by M. Bańbura, D. Giannone and L. Reichlin, November 2008.

967 "Central bank misperceptions and the role of money in interest rate rules" by V. Wieland and G. W. Beck, November 2008.

968 “A value at risk analysis of credit default swaps” by B. Raunig and M. Scheicher, November 2008.

969 “Comparing and evaluating Bayesian predictive distributions of asset returns" by J. Geweke and G. Amisano, November 2008.

970 "Responses to monetary policy shocks in the east and west of Europe" by M. Jarociński, November 2008.

97I "Interactions between private and public sector wages" by A. Afonso and P. Gomes, November 2008.

972 "Monetary policy and housing prices in an estimated DSGE for the US and the euro area" by M. Darracq Pariès and A. Notarpietro, November 2008.

973 “Do China and oil exporters influence major currency configurations?" by M. Fratzscher and A. Mehl, December 2008.

974 "Institutional features of wage bargaining in 23 European countries, the US and Japan" by P. Du Caju, E. Gautier, D. Momferatou and M. Ward-Warmedinger, December 2008.

975 "Early estimates of euro area real GDP growth: a bottom up approach from the production side" by E. Hahn and F. Skudelny, December 2008.

976 "The term structure of interest rates across frequencies" by K. Assenmacher-Wesche and S. Gerlach, December 2008.

977 "Predictions of short-term rates and the expectations hypothesis of the term structure of interest rates" by M. Guidolin and D. L. Thornton, December 2008.

978 "Measuring monetary policy expectations from financial market instruments" by M. Joyce, J. Relleen and S. Sorensen, December 2008.

979 “Futures contract rates as monetary policy forecasts" by G. Ferrero and A. Nobili, December 2008.

980 "Extracting market expectations from yield curves augmented by money market interest rates: the case of Japan" by T. Nagano and N. Baba, December 2008.

98I "Why the effective price for money exceeds the policy rate in the ECB tenders?" by T. Välimäki, December 2008.

982 "Modelling short-term Interest rate spreads in the euro money market?" by N. Cassola and C. Morana, December 2008.

983 "What explains the spread between the euro overnight rate and the ECB's policy rate?" by T. Linzert and S. Schmidt, December 2008.

984 “The daily and policy-relevant liquidity effects" by D. L. Thornton, December 2008. 
985 "Portuguese banks in the euro area market for daily funds" by L. Farinha and V. Gaspar, December 2008.

986 “The Topology of the Federal Funds Market” by M. L. Bech and E. Atalay, December 2008.

987 "Probability of informed trading on the euro overnight market rate: an update" by J. Idier and S. Nardelli, December 2008.

988 "The interday and intraday patterns of the overnight market: evidence from an electronic platform" by R. Beaupain and A. Durré, December 2008.

989 “Modelling loans to non-financial corporations in the euro area” by C. Kok Sørensen, D. Marqués lbáñez and C. Rossi, January 2009.

990 “Fiscal policy, housing and stock prices” by A. Afonso and R. M. Sousa, January 2009.

991 “The macroeconomic effects of fiscal policy” by A. Afonso and R. M. Sousa, January 2009. 
